\title{
Appraisal of measurement methods, chemical composition and sources of fine atmospheric particles over six different areas of Northern Belgium
}

László Bencs ${ }^{\mathrm{a} \ddagger}$, Khaiwal Ravindra, ${ }^{\mathrm{a}, \mathrm{b}}$, Johan de Hoog ${ }^{\mathrm{a}}$, Zoya Spolnik ${ }^{\mathrm{a}}$, Nico Bleux ${ }^{\mathrm{c}}$, Patrick Berghmans $^{c}$, Felix Deutsch ${ }^{c}$, Edward Roekens $^{d}$, René Van Grieken ${ }^{\mathrm{a}}$

${ }^{a}$ Micro and Trace Analysis Centre, Department of Chemistry, University of Antwerp, Universiteitsplein 1, B-2610 Antwerp, Belgium

${ }^{\mathrm{b}}$ Centre for Atmospheric and Instrumentation Research (CAIR), University of Hertfordshire, Hatfield, AL10 9AB, United Kingdom

${ }^{\mathrm{c}}$ Flemish Institute for Technological Research (VITO), Boeretang 200, B-2400 Mol, Belgium

${ }^{\mathrm{d}}$ Flemish Environment Agency (VMM), Kronenburgstraat 45, B-2000 Antwerp, Belgium

\section{Abstract -}

Daily and seasonal variation in the total elemental, organic carbon (OC) and elemental carbon (EC) content and mass of $\mathrm{PM}_{2.5}$ were studied at industrial, urban, suburban and agricultural/rural areas. Continuous (optical Dustscan, standard tapered element oscillating microbalance (TEOM), TEOM with filter dynamics measurement system), semi-continuous (Partisol filter-sampling) and noncontinuous (Dekati-impactor sampling and gravimetry) methods of $\mathrm{PM}_{2.5}$ mass monitoring were critically evaluated. The average elemental fraction accounted for 2-6\% of the $\mathrm{PM}_{2.5}$ mass measured by gravimetry. Metals, like $\mathrm{K}, \mathrm{Mn}, \mathrm{Fe}, \mathrm{Cu}, \mathrm{Zn}$ and $\mathrm{Pb}$ were strongly inter-correlated, also frequently with non-metallic elements ( $\mathrm{P}, \mathrm{S}, \mathrm{Cl}$ and/or $\mathrm{Br}$ ) and EC/OC. A high OC/EC ratio (2-9) was generally observed. The total carbon content of $\mathrm{PM}_{2.5}$ ranged between 3-77 \% (averages: 12-32 \%), peaking near industrial/heavy trafficked sites. Principal component analysis identified heavy oil burning, ferrous/non-ferrous industry and vehicular emissions as the main sources of metal pollution.

Capsule: This work compares $\mathrm{PM}_{2.5}$ monitoring methods to characterize $\mathrm{PM}_{2.5}$ over six locations of different anthropogenic activities over Northern Belgium.

Keywords: respirable particles, $\mathrm{PM}_{10}$, heavy metals, mineral content, EDXRF analysis, soot, multivariate analysis, non-exhaust emission.

* Correspondence author. Permanent address: Research Institute for Solid State Physics and Optics, Hungarian Academy of Sciences, Budapest, Hungary, E-mail address: laszlo.bencs@ua.ac.be, or bencs@ szfki.hu; Tel.: +36-1-392-2222/ ext. 1684; Fax: +36-1-392-2223 


\section{Introduction}

The fine fraction of suspended particulate matter (SPM) is generally referred as $\mathrm{PM}_{2.5}$ in the literature, i.e., any particle with an aerodynamic diameter below $2.5 \mu \mathrm{m}$. Particulates in this size range have been reported to be responsible for adverse health effects in humans (Pope and Dockery, 2006). $\mathrm{PM}_{2.5}$ aerosols also affect the local air quality of populated areas by impairing visibility and contribution to acid precipitation (IPCC, 2007; Harrison et al., 2004). Fine particulates play a direct role in global climate change by absorbing and scattering the solar radiation, thereby altering the total radiation budget of the Earth-atmosphere system (IPCC, 2007), and an indirect role by changing the depth and albedo of clouds (Twomey, 1974; IPCC, 2007). Due to the complexity in composition and impacts of $\mathrm{PM}_{2.5}$ aerosols, in addition to the need for their physical and chemical characterisation (e.g., metal content), it is also important to determine their sources, how they are formed, their distribution, and local and global transport mechanisms to achieve a better understanding of these aerosols, and to evaluate their risks to human health (Maenhaut, 2008).

Over most of the $\mathrm{PM}_{2.5}$ size range, carbonaceous particles in the atmosphere have been shown to be composed of elemental carbon (EC) and organic carbon (OC) (Putaud et al., 2004). The EC has a chemical structure close to that of impure graphite (Chen et al., 2003). EC originates from direct emission of particles from various anthropogenic sources, mainly from combustion (e.g., diesel engines) (Lim et al., 2002). OC originates from both direct emission of particles and atmospheric transformation of organic (gaseous) compounds. Secondary OC has been reported to be generated by condensation of low vapour pressure products during the photooxidation of hydrocarbons (Chow et al., 1996).

In the present study, daily, seasonal and site-specific variations in the elemental, EC and OC content and the mass of $\mathrm{PM}_{2.5}$ aerosols were evaluated to identify their chemical composition and sources at six locations of diverse anthropogenic influence in Northern Belgium. Furthermore, continuous, semi-continuous and non-continuous sampling and/or monitoring techniques and analytical chemical methods were applied and critically assessed to aid the decision-making process for $\mathrm{PM}_{2.5}$ monitoring and to reduce the bias in the environmental analyses performed. 


\section{Experimental}

\subsection{Sampling site characteristics}

Six sampling sites, representative of different anthropogenic influences in Northern Belgium (called as Flanders, Fig. 1), were selected: (1) Petroleumkaai (industrial site), the harbour of Antwerp surrounded with several petroleum processing plants, oil refineries and other oil industrial plants; (2) Borgerhout, one of the central districts of Antwerp with high density urban traffic (40-50 thousand cars/day) and also influenced by a non-ferrous industrial site of Hoboken within $5 \mathrm{~km}$ distance - a nearby district of Antwerp; (3) Zelzate (suburban site) - at the junction point of a busy main-road of the town with three smaller roads (but lower traffic density than that at Borgerhout) and a petrol station, close to a heavily travelled motorway (A11) and a highway (R4), and also nearby steel industry; (4) Hasselt (suburban site, channel-side with modest traffic density, i.e., shipping at nearby sluice gates and highway with medium/low traffic intensity); (5) Wingene (rural, agricultural area), negligibly low traffic, but certain agricultural activities (animal farming and crops); and (6) Mechelen (outskirts), relatively low traffic density, and some industrial impact, i.e., production of dyes and washing powder. Each location was visited in two, non-concurrent campaigns in diverse seasons of the year (Table 1). The most important meteorological parameters, such as wind-speed (WS), wind direction (WD), relative humidity $(\mathrm{RH})$, air temperature $\left(\mathrm{T}_{\mathrm{a}}\right)$, air pressure $\left(\mathrm{P}_{\mathrm{a}}\right)$ and the half hourly amount of precipitation (PR) were also recorded during the sampling campaigns at weather stations located near the sampling sites.

\subsection{Sampling of particulate matter}

\subsubsection{Continuous monitoring}

For the continuous monitoring of $\mathrm{PM}_{2.5}$, Rupprecht \& Patashnick (R\&P, Thermo Fischer Scientific, East Greenbush, NY, USA) Model 1400 tapered element oscillating microbalance (TEOM) units were used, each fitted with a $\mathrm{PM}_{2.5}$ Sharp-Cut Cyclone inlet. The inlet was preheated to $40{ }^{\circ} \mathrm{C}$ or $50{ }^{\circ} \mathrm{C}$, to eliminate the effect of condensation or evaporation of water particles. For a short period in Borgerhout, a TEOM was equipped with a filter dynamics measurement system (FDMS), which calculates PM-concentrations based on separate ambient air and reference $\left(\right.$ at $\left.4{ }^{\circ} \mathrm{C}\right)$ 
89 measurements. Using a splitter, the sampled air is alternately sent for 6 min to the measurement (at

90 the conditioning temperature of $30-50{ }^{\circ} \mathrm{C}$ ), either directly, or after filtration at $4{ }^{\circ} \mathrm{C}$. Thus it can be

91 used to detect the vaporization losses encountered with a standard TEOM. The concentration of

$92 \mathrm{PM}_{2.5}$ was also optically monitored (i.e., scattering measurements) with the application of an $\mathrm{R} \& \mathrm{P}$

93 Dust Monitor (Dustscan).

95 2.2.2. Non-continuous sampling and gravimetry

96 Daily (24 h), size-fractionated aerosols at a height of $\sim 1.8 \mathrm{~m}$ above ground level were

97 occasionally sampled using a four-stage Dekati-impactor with an airflow rate of $30 \mathrm{dm}^{3} \mathrm{~min}^{-1}$.

98 Nuclepore-filters with a diameter of $25 \mathrm{~mm}$ and a pore-size of $0.2 \mu \mathrm{m}$ were fitted onto the three,

99 upper-stage impactor-plates, corresponding to $>\mathrm{PM}_{10}, \mathrm{PM}_{10-2.5}$, and $\mathrm{PM}_{2.5-1}$, fractions, respectively. A

100 Whatman filter with a diameter of $47 \mathrm{~mm}$ was placed onto the bottom of the impactor to collect the

101 "back-up" $\left(\mathrm{PM}_{1}\right)$ fraction. The filters were weighed on a micro-balance (Sartorius model M5P-

102 000V001, Göttingen, Germany) before and after sampling according to the EN12341 protocol. The

103 TSP, $\mathrm{PM}_{10}$, and $\mathrm{PM}_{2.5}$ data were calculated from the masses of diverse fractions deposited on the

104 different stages of the impactor.

105

106 2.2.3. Daily sampling of $\mathrm{PM}_{2.5}$ and $\mathrm{PM}_{10}$ for EDXRF analysis

107 Automated R\&P Model Partisol Plus samplers and an ESM Eberline Model FH95 SEQ

108 (Eberline Instruments $\mathrm{GmbH}$, Germany) were used for the daily sampling of $\mathrm{PM}_{2.5}$ and $\mathrm{PM}_{10}$,

109 respectively, with an airflow rate of $1 \mathrm{~m}^{3} \mathrm{~h}^{-1}$. Various types of filters of $47 \mathrm{~mm}$ diameter and $0.8 \mu \mathrm{m}$

110 porosity were tested, e.g., Teflon, cellulose nitrate, and cellulose acetate. The latter filter material was

111 used for sampling the total elemental content, since it gave the lowest blanks for XRF-analysis. After

112 removing the samples from the sampling instruments, they were stored in a cooling box and

113 transported to the laboratory, where they were kept in a fridge (below $4^{\circ} \mathrm{C}$ ) till sample processing.

114 The filters were subjected to gravimetric analysis (see Section 2.2.2.). However, the gravimetric

115 analysis of the cellulose acetate filters was influenced by the tendency to be electrostatically charged, 
116 which resulted in a certain deviation in the measured filter masses. For this reason, only the

117 gravimetric results for Teflon-filters were taken into consideration.

119 2.3. Analytical methods and instrumentation

120 2.3.1. Energy dispersive X-ray fluorescence spectrometry (EDXRF)

121 The EDXRF analysis was performed on a Tracor Spectrace 5000 instrument, which uses a

122 low power Rh-anode X-ray tube $(17.5 \mathrm{~W})$. The characteristic X-ray radiation was detected by a

$123 \mathrm{Si}(\mathrm{Li})$ detector. For determining high-Z elements (starting from $\mathrm{K}$ ), an accelerating voltage of $35 \mathrm{kV}$

124 and a current of $0.35 \mathrm{~mA}$ were used. The acquisition time was set at $10000 \mathrm{~s}$. Low-Z elements (from

$125 \mathrm{Al}$ to $\mathrm{Cl}$ ) were measured at $10 \mathrm{kV}$ and $0.35 \mathrm{~mA}$ with an acquisition time of $4000 \mathrm{~s}$. The measured

126 intensities were converted into elemental concentrations by the AXIL (analysis of X-ray spectra by

127 non-linear iterative least-squares) program (Vekemans et al., 1994). The limit of detection (LOD)

128 values for $\mathrm{Al}, \mathrm{Si}, \mathrm{K}, \mathrm{Ca}, \mathrm{Ti}, \mathrm{V}, \mathrm{Cr}, \mathrm{Mn}, \mathrm{Fe}, \mathrm{Ni}, \mathrm{Cu}, \mathrm{Zn}, \mathrm{Se}, \mathrm{Br}, \mathrm{Rb}, \mathrm{Sr}$ and $\mathrm{Pb}$ ranged from 3.8 to 12.6

$129 \mathrm{ng} \mathrm{m}^{-3}$ for air samples. The precision of the determinations expressed as the relative standard

130 deviation (RSD) was generally better than $1 \%$ for the high-Z elements, but it was around $5 \%$ for $\mathrm{Al}$,

131 Si, P, S and Cl (Samek et al., 2002).

133 2.3.2. Monitoring of organic and elemental carbon

134 Particulate carbon was monitored with an Ambient Carbon Particulate Monitor (ACPM)

135 Model $5400(\mathrm{R} \& \mathrm{P})$ fitted with a Stairmand $\mathrm{PM}_{2.5}$ cyclone head. Air was sampled at a flow-rate of

$13616.71 \mathrm{~min}^{-1}$ on the impaction plate (with a $50 \%$ effective aerosol cut-off diameter of $0.14 \mu \mathrm{m}$ ) of the

137 ACPM preheated at $50{ }^{\circ} \mathrm{C}$ to avoid the adsorption of gaseous organic compounds. The sampling

138 interval was set at $2 \mathrm{~h}$. As a first stage of the analysis, the samples were heated up to $340{ }^{\circ} \mathrm{C}$ to

139 decompose the organic species deposited. This step was followed by afterburning at $750{ }^{\circ} \mathrm{C}$. After

140 each analysis step, performed in a closed loop under atmospheric air, the $\mathrm{CO}_{2}$ concentration was

141 measured with a non-dispersive infrared detector, and the carbon content was calculated. The

142 concentrations obtained after the first and the second analysis stage correspond to the fractions of OC

143 and EC, respectively. 
It is to be noted that the ACPM may suffer from positive sampling artifacts, which depend on

145 the working-temperatures of its impactor plate (Matsumoto et al., 2003). However, the influence of

146 these artifacts on the measurement of OC collected for longer sampling intervals (e.g., 2 h),

147 especially at its higher concentrations, and evolved at a higher temperature $\left(250-340{ }^{\circ} \mathrm{C}\right)$ and $\mathrm{EC}$ in

148 aerosols could involve less uncertainty (Matsumoto et al., 2003). It should also be mentioned that EC

149 readings from the standard ACPM have been found to be lower than those from a modified-ACPM,

150 due to the fine aerosol cut-off, as above (ten Brink et al., 2005). Because of this negative bias, the

151 standard ACPM technique is just reliable in a sense to make an estimation of the EC/OC values.

153 2.4. Data evaluation and statistics

154 The analytical data were statistically treated using the SPSS software package (version 14.0).

155 Bivariate correlation analysis was performed by calculating the Pearson's correlation coefficient at

156 two-tailed significance levels (i.e., corresponding to correlations significant either at the $\mathrm{p}=0.05$ or

$157 \mathrm{p}=0.01$ levels, respectively). The daily metal levels were also processed using the principal 158 component analysis (PCA) with varimax rotation and Kaiser Normalization. Only principal 159 components (PCs) having an eigenvalue in the component data set higher than unity before varimax 160 rotation were retained.

\section{3. Results and discussion}

163 3.1. Assessment of $\mathrm{PM}_{2.5}$ dust monitoring methods

164 3.1.1. Bias experienced with optical methods

165 The temporal evolution of the $\mathrm{PM}_{2.5}$ mass curves from the optical Dustscan was very similar 166 to those of gravimetric methods, but its absolute values were strikingly higher (Fig. 2). Since this 167 mass deviation rather randomly changed, it was not possible to specify an exact factor/function for 168 this inaccuracy. Dustscan, like other optical methods, is usually calibrated against so-called "standard 169 aerosols". However, the morphology and composition of atmospheric aerosols can change rapidly 170 over time and location, which can cause a bias in the optical measurements. 
3.1.2. TEOM versus gravimetric particulate measurements

The $\mathrm{PM}_{2.5}$ levels from gravimetry were significantly higher than those of the standard TEOM

174 (Fig. 3). This bias is due to the temperature conditioning of the air stream in the TEOM (cf. Section

175 2.2.1.), which treatment can cause mass loss through evaporation of volatile components in $\mathrm{PM}_{2.5}$,

176 e.g., ammonium nitrate $\left(\mathrm{NH}_{4} \mathrm{NO}_{3}\right)$ (Charron et al., 2004), semi-volatile organic compounds (Vecchi

177 et al., 2009), and water attached to aerosol particles due to their hygroscopic nature, even at as low

178 temperatures as $25-30{ }^{\circ} \mathrm{C}$. This finding was verified by simultaneous monitoring of $\mathrm{PM}_{2.5}$ in

179 Mechelen in the second campaign with two TEOM units, applying conditioning temperatures of 50

$180{ }^{\circ} \mathrm{C}$ and $40{ }^{\circ} \mathrm{C}$, respectively (Table 2). A Partisol sampler working at $20{ }^{\circ} \mathrm{C}$ was used as a reference.

181 No mathematical correction for $\mathrm{NH}_{4} \mathrm{NO}_{3}$ evaporation losses was applied in these experiments, as 182 usually recommended when applying standard TEOM methods (Charron et al., 2004). It is to be 183 noted that $\mathrm{NH}_{4} \mathrm{NO}_{3}$ has been found in $\mathrm{PM}_{2.5}$ in concurrent samples of the same sites (Bencs et al., 184 2008). As expected, an increase in the conditioning/sampling temperature resulted in a decrease in 185 the daily $\mathrm{PM}_{2.5}$ mass (see Table 2 and Fig. 3).

186 Comparing the standard TEOM and TEOM-FDMS results, an obvious discrepancy can be 187 seen between the two $\mathrm{PM}_{2.5}$ data series (Fig. 3). On the other hand, the TEOM-FDMS values approach very well those from Partisol sampling and gravimetry. Thus they exhibit a more accurate monitoring of $\mathrm{PM}_{2.5}$ than the methods involving the use of mathematical correction factors.

Interestingly, the $\mathrm{PM}_{2.5}$ mass data in Mechelen showed a contradicting trend (Fig. 4), i.e., a reverse pattern on most sampling days (i.e., Partisol< TEOM $\left(40{ }^{\circ} \mathrm{C}\right)<$ TEOM $\left(50{ }^{\circ} \mathrm{C}\right)$ ). The same trend could be observed for Petroleumkaai in the $1^{\text {st }}$ campaign and for Wingene and Zelzate in the $2^{\text {nd }}$ campaign. Moreover, the $\mathrm{PM}_{10}$ results of TEOM and Eberline appeared to behave the same way. The change in the daily average temperature $\left(\mathrm{T}_{\mathrm{da}}\right)$ may offer a possible explanation. On those days, when the expected difference between $\mathrm{PM}_{2.5}$ data of TEOM and gravimetry did not occur, $\mathrm{T}_{\mathrm{da}}$ was always higher than $15^{\circ} \mathrm{C}$, which led to the following conclusions:

(1) When the ambient air temperature is high enough (e.g., $\mathrm{T}_{\mathrm{da}}>15^{\circ} \mathrm{C}$ ), a part of the volatile compounds is already evaporated before/during sampling. Therefore, the temperature conditioning in TEOM has a less pronounced, or even negligible effect on $\mathrm{PM}_{2.5}$ values, i.e., the data are in 
200 agreement independently of the temperature of conditioning. Since the Partisol filters were measured

201 passing some days (sometimes two weeks) after the sampling, they were longer exposed to

202 fluctuating outdoor conditions and generally higher indoor (laboratory) temperatures than the outdoor

203 temperatures. This can cause additional evaporation of volatile sample components, which results in

$204 \mathrm{PM}_{2.5}$ values lower than those obtained from TEOM.

(2) When $\mathrm{T}_{\mathrm{da}}$ is lower than $15{ }^{\circ} \mathrm{C}$, the conditioning effect in TEOM is larger and the Partisol

206 filters are preserved much better during their stay in the sampling units, due to the low evaporation 207 losses.

208 (3) The fact that $\mathrm{PM}_{10}$ concentrations are less dependent on $\mathrm{T}_{\mathrm{da}}$ during summer campaigns, 209 could be explained by the fact that relatively coarser particles are present in the air and a considerable 210 part of $\mathrm{NH}_{4} \mathrm{NO}_{3}$ exists in air by evaporation, due to the drier and warmer weather. Certainly, the 211 coarse particles present in the $\mathrm{PM}_{10-2.5}$ fraction are less prone to vaporization than most fine particles 212 in $\mathrm{PM}_{2.5}$. The fine particles can be more easily vaporized than coarse particulates, due to the changing

213 in their solid state characteristics with a decreasing aerodynamic diameter (e.g., melting and boiling

214 point). That's why, their masses affect the $\mathrm{PM}_{10}$ measurements to a larger extent, and the influence of

$215 \mathrm{~T}_{\mathrm{da}}$ does not prevail so clearly. In cold periods with a high precipitation rate, such as in Mechelen in 216 the second campaign (Table 1), the less coarse particles remain in the air. Hence, $\mathrm{PM}_{10}$ could 217 evidently be more influenced by evaporation effects.

219 3.1.3. Site-specific variation in the levels of $\mathrm{PM}_{2.5}$

220 The highest average daily concentrations of $\mathrm{PM}_{2.5}$ were observed in Borgerhout, i.e., $29 \pm 15$ $221 \mu \mathrm{g} \mathrm{m}^{-3}$ and $45 \pm 22 \mu \mathrm{g} \mathrm{m}^{-3}$ for the first and second campaigns, respectively (Table 3 ). The highest daily 222 mean concentration of $\mathrm{PM}_{2.5}$ was also experienced in Borgerhout $\left(99.7 \mu \mathrm{g} \mathrm{m}^{-3}\right)$ in the second 223 campaign. A strong linear correlation was found between the $\mathrm{PM}_{2.5}$ and $\mathrm{PM}_{10}$ concentrations. The $224 \mathrm{PM}_{2.5}$ contribution to the $\mathrm{PM}_{10}$ levels was the highest in Borgerhout (i.e., $71 \%$ on average; and $92 \%$ 225 maximum), which means that most of the particles were present in the fine to ultra-fine particle range 226 at this site. 
In view of the new European Directive (ED), it might be interesting to evaluate the measured concentrations and to check if they meet the proposed $\mathrm{PM}_{2.5}$ limit values of yearly average of $25 \mu \mathrm{g}$ $\mathrm{m}^{-3}$ (European Directive, 2008). Since only a maximum of three-month-long monitoring was carried

230 out at each location, it was only possible to make a prediction based on extrapolation with this

231 limited data set. These daily average $\mathrm{PM}_{2.5}$ values have already exceeded the ED-limit for three sites

232 in the first campaign and for Borgerhout in the second campaign (Table 3). However, if taking into

233 account the overall campaign averages, only the levels at Borgerhout $\left(38 \mu \mathrm{g} \mathrm{m}^{-3}\right)$ were found above

234 the ED-limit (Table 4).

The average yearly concentration of $\mathrm{PM}_{2.5}$ at each sampling location was calculated by an extrapolation scheme using the average daily $\mathrm{PM}_{2.5}$ concentrations for the sampling campaigns at each site and a correction factor based on the proportion of the average concentrations monitored 238 during the same period and over a whole year at other three reference locations. In this way, it was 239 possible to avoid over- or underestimations, due to unforeseen, general seasonal variations. The 240 yearly average $\mathrm{PM}_{2.5}$ concentration for the three reference locations (Mechelen-Zuid, Mechelen-

241 Nekkerspoel and the Brussels-Zaventem) in 2002 was $16 \mu \mathrm{g} \mathrm{m}^{-3}$; the average for the same period as 242 in Borgerhout was $21 \mathrm{gg} \mathrm{m}^{-3}$ (Table 4). These results are also in agreement with the annual mean $243 \mathrm{PM}_{2.5}$ level of $17 \mu \mathrm{g} \mathrm{m}^{-3}$ reported for Menen, Belgium (Ravindra et al., 2008). Therefore, one could 244 already assume that the very high average value of $38 \mu \mathrm{g} \mathrm{m}^{-3}$ in Borgerhout was due to measurements 245 that were carried out in an episodic pollution period with very high $\mathrm{PM}_{2.5}$ levels. Thus the yearly 246 average for Borgerhout is expected to be lower than $38 \mu \mathrm{g} \mathrm{m} \mathrm{m}^{-3}$. According to the results of 247 extrapolation (Table 4), only the Borgerhout site would not meet the ED-limit.

249 3.1.4. Impact of meteorological conditions on the $\mathrm{PM}_{2.5}$ and $\mathrm{PM}_{10}$ mass

As would be expected, an increase in wind speed, precipitation, and/or RH decreased the $251 \quad \mathrm{PM}_{2.5}$ and $\mathrm{PM}_{10}$ levels (Supplementary Table 1). On the other hand, an increase in the air temperature 252 would be generally followed by an increase in the aerosol mass, i.e., particle accumulation. 253 However, this trend was experienced only for a couple of sites, like Borgerhout during the winter254 spring and Wingene in the summer campaign, while $\mathrm{T}_{\mathrm{a}}$ was rather anti-correlated with both $\mathrm{PM}_{2.5}$ 
and $\mathrm{PM}_{10}$ aerosols at the other sites/campaigns. This was likely due to the fairly high percent of volatile fraction of aerosols, e.g., $\mathrm{NH}_{4} \mathrm{NO}_{3}$ (Bencs et al., 2008), the increase in $\mathrm{T}_{\mathrm{a}}$ allowed their vaporization in both particulate fractions.

259 3.2. Elemental composition of $\mathrm{PM}_{2.5}$

260 3.2.1. Ratio of elements in $\mathrm{PM}_{2.5}$

The elemental content was found to be at a relatively low, but highly fluctuating percentage in $\mathrm{PM}_{2.5}$, ranging from 0.1 to $24 \%$ with an average of $3.4 \%$ (Table 5). As a general observation, peak levels of elements in $\mathrm{PM}_{2.5}$ (i.e., values generally higher than $10 \%$ of the total $\mathrm{PM}_{2.5}$ mass) were found at sites with industrial impact (Zelzate, Mechelen and Petroleumkaai). In Hasselt, the elemental fraction was higher only in the second campaign, which is likely due to some industrial impact as well as the ship-traffic nearby this location, and the prevailing winds from the west. As expected, at the rural site of Wingene a lower percentage of elements were found in $\mathrm{PM}_{2.5}$, i.e., up to

$6.3 \%$, when the maximum observations were considered. These findings show the importance of industrial emission of metals and the lower impact of the traffic. The calculated total-element-to$\mathrm{PM}_{2.5}$ ratios are comparable with those observed for the city of Ghent in Belgium (3-4 \%) (Viana et al., 2007) and for Central European cities (2-5\%), but much lower than those for North and South

272 European cities with values of 15-40\% and 8-20\%, respectively (Querol et al., 2004).

274 3.2.2. Influence of anthropogenic activities on the elemental content of $\mathrm{PM}_{2.5}$ The elemental content in $\mathrm{PM}_{2.5}$ showed high site-specific variations (Table 6). Non-metallic elements, such as $\mathrm{P}, \mathrm{S}, \mathrm{Cl}, \mathrm{Se}$ and $\mathrm{Br}$, were also detected at significant air levels, ranging from 14$277302,9.9-4600,9-2400,1.1-28$ and 2-91 $\mathrm{ng} \mathrm{m}^{-3}$, respectively. The highest total concentrations of 278 elements were found at sites under industrial influence (Zelzate, Petroleumkaai, and Borgerhout).

279 The cold seasons were characterized with increased metal content of $\mathrm{PM}_{2.5}$ (e.g., $\mathrm{K}, \mathrm{V}, \mathrm{Fe}, \mathrm{Ni}$, and $280 \mathrm{Zn})$. The total elemental content $\left(200-1100 \mathrm{ng} \mathrm{m}^{-3}\right)$, irrespective of the nature of the sampling site, is 
282 Ghent (Viana et al., 2007), but generally lower than those from North and South European cities with 283 1000-6000 $\mathrm{ng} \mathrm{m}^{-3}$, respectively (Querol et al., 2004).

284 Fairly high concentrations of $\mathrm{Al}, \mathrm{Si}, \mathrm{K}, \mathrm{Ca}$ and $\mathrm{Fe}$, i.e., up to a few hundred $\mathrm{ng} \mathrm{m}^{-3}$, were 285 generally found at each site (Table 6). Most of these elements have a crustal origin (Maenhaut et al., 286 2007), although some of them in $\mathrm{PM}_{2.5}$ may have an anthropogenic origin. For instance, Oravisjärvi 287 et al. (2003) have pointed out Li, F, Na, Mg, Al, K, Ca, Mn, Fe, Zn, Cd and Pb at enhanced 288 atmospheric levels in the vicinity of steel-works. Most of these elements were also found at increased 289 air levels at Zelzate (Table 6). At this area, F has also been observed at a bit enhanced level 290 compared to the other sites (Bencs et al., 2008). The highest $\mathrm{K}$ content was found at Borgerhout 291 during the cold season, which is likely due to the presence of biogenic materials (e.g., wood and coal 292 combustion). Similarly high K levels were observed in Zelzate during winter and also in Hasselt 293 during autumn.

$294 \mathrm{Zn}$ and $\mathrm{Pb}$ were present at lower levels than the former elements, but still at significant 295 concentrations (Table 6). The highest levels were at industrial/heavy trafficked sites (Zelzate and 296 Borgerhout). $\mathrm{Pb}$ is also associated with non-biomass burning sources, like fossil fuel combustion and 297 the non-ferrous industry (Nriagu and Pacyna, 1988). The nearby presence of a precious metal 298 refinery in Hoboken, i.e., within $5 \mathrm{~km}$ of the sampling site of Borgerhout, supports this possibility. 299 Also, coal-burning (e.g., in power stations) can be an emission source of $\mathrm{Zn}$ and $\mathrm{Pb}$, as well as 300 increase the air concentrations of other heavy metals like $\mathrm{Cr}, \mathrm{Ni}, \mathrm{Cu}$ and $\mathrm{Cd}$ (Keegan et al., 2006). In 301 urban areas, the brake lining of vehicles is a major source of $\mathrm{Cu}, \mathrm{Zn}, \mathrm{Cd}, \mathrm{Sb}$ and $\mathrm{Pb}$ (Hjortenkrans et 302 al., 2007).

$303 \mathrm{Ti}, \mathrm{V}, \mathrm{Cr}, \mathrm{Mn}, \mathrm{Ni}, \mathrm{Cu}$ and $\mathrm{Rb}$ were present at levels lower than $\sim 10 \mathrm{ng} \mathrm{m}^{-3}$ in $\mathrm{PM}_{2.5}($ Table 304 6). Sr was measured in well detectable amounts only at Zelzate during the first campaign (average: 1 $305 \mathrm{ng} \mathrm{m}^{-3}$ ), which is likely due to the nearby steel industry. $\mathrm{Cu}$ was found at elevated levels at the heavy 306 trafficked Borgerhout. $\mathrm{V}$ and $\mathrm{Ti}$ were detected at increased atmospheric concentrations at the 307 industrial/heavy trafficked sites. Interestingly, V was also observed at fairly enhanced levels at the 308 agricultural Wingene during both campaigns. This could be due to the heavy diesel emission from 
309 vehicles used over the crops. The V-to-Ni ratio of $\sim 2$ supports this assumption (Maenhaut et al., 310 2007).

312 3.3. Source identification of elements in $\mathrm{PM}_{2.5}$

313 3.3.1. Correlation analysis

314 3.3.1.1. General trends over sites and campaigns

315 Some of the elements, mostly originating from anthropogenic emissions, like $\mathrm{K}, \mathrm{Mn}, \mathrm{Fe}, \mathrm{Cu}$,

$316 \mathrm{Zn}$ and $\mathrm{Pb}$, further referred to as the "base-group", were strongly correlated with each other

317 (Supplementary Table 1). Moreover, they were frequently correlated with non-metallic elements, like

$318 \mathrm{P}, \mathrm{S}, \mathrm{Cl}$ and/or $\mathrm{Br}$, and also with $\mathrm{EC}$ and $\mathrm{OC}$. The correlation of $\mathrm{Fe}, \mathrm{Zn}, \mathrm{Cu}, \mathrm{Ba}$ and $\mathrm{EC}$ suggests

319 traffic/vehicular sources (Viana et al., 2008).

320 Generally, the anthropogenic elements were strongly correlated with elements mostly of 321 crustal origin, e.g., $\mathrm{Al}, \mathrm{Ca}$, and/or $\mathrm{Si}$, Ti. Monitoring data from a background site indicate $\mathrm{Si}-\mathrm{Al}-\mathrm{Fe}-$, 322 Si-, Ca-S-Si-, Ca-Si-, Fe-Si-, and Ti-Si-rich particles as typical soil elements (Hoornaert et al., 2004).

323 These elements in $\mathrm{PM}_{2.5}$ can also originate from anthropogenic sources. However, an enrichment 324 factor of higher than unity has been observed only for $\mathrm{Ca}$ and $\mathrm{Ti}$ over Uccle, an urban background 325 site in Belgium, i.e., 10 and 3, respectively (Maenhaut et al., 2007). Therefore, a rather crustal origin 326 has been presumed for the atmosphere over Flanders.

Cr was usually correlated with some elements of the base-group, which points to common 328 sources. $\mathrm{Cr}$ is mostly associated with traffic/vehicular emission (Viana et al., 2008; Hu et al., 2009) 329 and industrial combustion (e.g., coal-fuelled power plants (Keegan et al., 2006) and coke ovens 330 (Wang et al., 2003)). Ni was correlated with $\mathrm{Cu}$ over most of the sites, which can be interpreted as a 331 signature of oil combustion (Pio et al., 1989). Rb was generally well correlated with EC, OC and the 332 elements of the base-group at sites with industrial influence. $\mathrm{Sr}$ was usually correlated with $\mathrm{Al}$ and/or $333 \mathrm{Si}$, which shows its origin mostly of crustal sources. The most interesting site/campaign-specific 334 correlations are discussed as follows. 
In Zelzate, besides the base-group, $\mathrm{K}$ was also correlated with $\mathrm{Ni}$ and $\mathrm{Sr}$, in the winter campaign, and with $\mathrm{V}$ and $\mathrm{Rb}$ in the summer-autumn campaign. These elements and Fe were closely correlated to each other in both campaigns, thus they most probably originate from the neighbouring

340 steel industry. Interestingly, they were also correlated with $\mathrm{Al}$ and/or $\mathrm{Si}$, which is usually of crustal 341 origin, but for $\mathrm{Al}$ studies also suggest combustion related sources in $\mathrm{PM}_{2.5}$ (e.g., steel industry 342 Oravisjärvi et al., 2003). In the winter campaign, $\mathrm{Ca}$ was correlated well with $\mathrm{P}, \mathrm{Ni}$ and $\mathrm{Cu}$, which 343 suggests that a part of the Ca likely comes from re-suspended road dust. In the winter campaign, V 344 was well correlated with $\mathrm{Br}$ and $\mathrm{P}$, but in the summer-autumn campaign, it was strongly correlated 345 with Ni and Si. According to Maenhaut et al. (2007), V and Ni have a source of vehicular emission 346 and heavy oil burning. At Zelzate, V likely originates from the diesel traffic, but also, a part of it 347 might come from the re-suspended road dust, as observed by Oravisjärvi et al. (2003). Ti might 348 originate partly from the steel industry, since it was strongly correlated with Fe and the other steel349 industry related elements as above and EC in the summer-autumn campaign, but a part of it might 350 also come from crustal sources (Maenhaut et al., 2007) and/or re-suspended road dust (Oravisjärvi et 351 al., 2003).

The emission of a petrochemical plant has been characterized with increased $\mathrm{S}, \mathrm{V}, \mathrm{Ni}, \mathrm{Zn}$ and Se content of $\mathrm{PM}_{2.5}$ (Bosco et al., 2005), which results in correlation of these elements. In

354 Petroleumkaai, the base-group, EC and OC were correlated with $\mathrm{V}$ and/or $\mathrm{Ni}$, which points to a 355 source of the nearby heavy oil burning activities. In the autumn campaign, Ti was correlated with the 356 crustal Al, Si, but also with $\mathrm{P}$ and $\mathrm{Se}$, while in the winter campaign, it was strongly correlated with $\mathrm{V}$ and $\mathrm{Si}$, thus it partly originates from the oil refinery emissions.

In the heavy trafficked Borgerhout, besides the base-group and crustal elements, Ca was also

359 correlated strongly with $\mathrm{Ti}, \mathrm{Cr}$, non-metallic elements and $\mathrm{EC}$, thus they possibly come from road 360 dust re-suspension. Ti was correlated with $\mathrm{V}, \mathrm{Ni}$ and $\mathrm{P}$ in the autumn-winter campaign, while it was 361 correlated with $\mathrm{V}, \mathrm{Cr}$, the base-group and crustal elements in the winter-spring campaign. Ni was 362 correlated well with EC and OC in the winter-spring campaign. Thus $\mathrm{Ti}$ and $\mathrm{Ni}$ were supposed to 363 originate from diesel emissions and heavy oil burning activities, e.g., the oil industry at 364 Petroleumkaai located northwest of Borgerhout. 
The suburban/riverside site at Hasselt showed a pattern of strong correlations of the basegroup with crustal ( $\mathrm{Al}, \mathrm{Si}$ and $\mathrm{Ca}$ ) and non-metallic (P, S and $\mathrm{Br}$ ) elements in both campaigns. Interestingly, $\mathrm{Cl}$ was strongly correlated with these elements too. $\mathrm{Cl}$ is of sea salt origin (Hoornaert et al., 2003). However, at Hasselt, the origin of $\mathrm{Cl}$ might be found in the nearby paper industry, which is a source of organic $\mathrm{Cl}$. Interestingly, Ni was strongly correlated with most of the detected elements, while $\mathrm{Ti}, \mathrm{V}$ and $\mathrm{Cr}$ were somewhat poorly correlated with any of them. $\mathrm{V}$ has also been observed to be poorly correlated in $\mathrm{PM}_{2.5}$ in Uccle, for which additional sources of $\mathrm{Ni}$ (e.g., non-ferrous industry) were presumed to be responsible (Maenhaut et al., 2007). This is likely true for the Mechelen site.

Hasselt, apart from the non-metallic elements, which were much less correlated with the others. For example, $\mathrm{Cl}$ was correlated only with $\mathrm{Ca}$ and $\mathrm{Ti}$, thus they likely originated from road dust resuspension. In the autumn-winter campaign, $\mathrm{EC}$ was correlated with $\mathrm{Fe}, \mathrm{Zn}$ and $\mathrm{Pb}$, . related to the use of diesel vehicles over nearby crops in the spring and summer seasons. In the spring campaign, Ti was correlated with $\mathrm{Ni}$ and $\mathrm{Br}$. Thus Ti likely also related to diesel fuel emissions. The correlation of $\mathrm{K}, \mathrm{Cr}, \mathrm{Mn}, \mathrm{Fe}, \mathrm{Zn}, \mathrm{Pb}$ and $\mathrm{EC}$ points to biomass burning (cf. Godoi et al., 2004).

\subsubsection{Principal component analysis (PCA)}

As the PCs were extracted successively, the first PC is more correlated with the variables than the second (Supplementary Tables 2-7). Hence, only the major PCs from each site were assessed for source characterization. The species having loadings above 0.7 were characterized "high" and those below 0.4 "low". The species having PC loading of less than 0.4 were considered either not be related to the other species or were explored in an additional PC (Costello and Osborne, 2005). indicates the presence of petroleum refinery and other industrial combustion activities, which are 390 dominant in this area. Further, PC 2 has high loadings of $\mathrm{Al}$ and Si with moderate loadings of $\mathrm{Ca}$ and

391 Rb. This PC reflects the contribution of crustal elements. At Borgerhout, PC 1 is highlighted by Al, 
393 influence of vehicular emission and suspension of road dust. Zn has been identified in tire wear 394 emission and Fe in brake-drum abrasion (Manoli et al., 2002). PC 2 has high Fe and Cu loadings with 395 relatively lower loadings of $\mathrm{Ca}, \mathrm{Zn}, \mathrm{Sr}$ and $\mathrm{Pb}$. This $\mathrm{PC}$ is indicative of non-exhaust emission sources 396 (e.g., wheel/brake abrasion of vehicles) with the influence of diesel exhaust, as well as the influence 397 of a nearby precious metal refinery. Although $\mathrm{Pb}$ has been phased out from petrol, generally, road 398 traffic emission remains one of the sources (Heal et al., 2005). Zelzate has high loadings of Al, Cl, K, $399 \mathrm{Zn}, \mathrm{Br}$ and $\mathrm{Pb}, \mathrm{Fe}$, with moderate loadings of $\mathrm{Si}, \mathrm{P}, \mathrm{S}$, and $\mathrm{Cu}$. This emission seems to be related to 400 the coke-oven industries in this area. PC 2 is represented by $\mathrm{P}, \mathrm{S}$ and $\mathrm{Cr}$ suggestive of the combustion activities in the vicinity.

PC 1 in Hasselt has high loadings of $\mathrm{Si}, \mathrm{S}, \mathrm{Cl}, \mathrm{K}, \mathrm{Ca}, \mathrm{Ni}, \mathrm{Cu}, \mathrm{Zn}, \mathrm{Br}$ and $\mathrm{Pb}$, which shows the 403 mixed influence of natural and vehicular/ship emissions. PC 2 is represented by $\mathrm{Cr}$ and Fe. High 404 loadings of $\mathrm{Fe}$ and $\mathrm{Cr}$ are suggestive of road dust (Manoli et al., 2002), but considerable $\mathrm{Cr}$ comes 405 also from mobile sources (e.g., brake wear emissions) nearby heavily trafficked roads (Hu et al., 406 2009). At Wingene, $\mathrm{K}, \mathrm{Fe}, \mathrm{Zn}$ and $\mathrm{Pb}$ show relatively higher PC loadings. In addition to the crustal 407 sources, $\mathrm{K}$ has been identified an important marker of biomass burning. Wingene is characterised as 408 a rural/agricultural area, thus biomass burning activities may be expected in this area. PC 2 has high 409 loadings of V, Mn and Ni. V and Ni are markers of fuel-oil (Heal et al., 2005), whereas the other 410 elements are likely due to local suspension of dust during agricultural practices. PC 1 at Mechelen is 411 highlighted by $\mathrm{Al}, \mathrm{Cl}, \mathrm{K}, \mathrm{Ca}, \mathrm{Cu}, \mathrm{Zn}, \mathrm{Se}$ and $\mathrm{Br}$. Interestingly, high loadings of $\mathrm{Br}$ and $\mathrm{Se}$ were 412 noticed only at this location. Br is frequently used in dye industries; whereas Se is mainly used in 413 glass manufacturing chemicals and pigments. This PC shows the influence of local industrial 414 activities on $\mathrm{PM}_{2.5}$ composition. PC 2 has high loadings of $\mathrm{Si}, \mathrm{P}, \mathrm{S}, \mathrm{Fe}, \mathrm{Rb}$ and $\mathrm{Pb}$. Some of these 415 elements can be related to the re-suspension of road dust (Heal et al., 2005), and hence, indicate their 416 relation with non-exhaust emissions. However, the presence of $\mathrm{S}$ and $\mathrm{P}$ also indicates industrial 417 combustion and biomass burning activities, respectively.

419 3.4. Elemental carbon and organic carbon content of $\mathrm{PM}_{2.5}$

420 3.4.1. Site-specific variation of EC and OC 
The daily concentrations of EC and OC determined non-concurrently with the ACPM over

422 various sites/campaigns are listed in Table 7. The minimum levels of EC ranged between 0.1-0.5 $\mu \mathrm{g}$

$423 \mathrm{~m}^{-3}$, while the maximum EC values were found to be between 1.1-4.4 $\mu \mathrm{g} \mathrm{m}^{-3}$. Amongst the studied

424 sites, Borgerhout and Petroleumkaai reported the highest EC levels in the first campaign, with values

425 of 3.3 and $4.4 \mu \mathrm{g} \mathrm{m}^{-3}$, respectively. The average level of EC was the highest also at the heavy

426 trafficked Borgerhout (1.3-1.5 $\mu \mathrm{g} \mathrm{m}^{-3}$ ), whereas sites with less traffic density showed much lower

427 concentrations $\left(0.3-0.6 \mu \mathrm{g} \mathrm{m}^{-3}\right)$. The exception was Petroleumkaai, with an increased average value

428 of $1.1 \mu \mathrm{g} \mathrm{m}^{-3}$ in the first campaign, likely due to the nearby industrial emissions combined with

429 warmer weather conditions. The maximum daily OC values were found to be at Mechelen (10 $\mu \mathrm{g} \mathrm{m}$

$430{ }^{3}$ ) and Petroleumkaai $\left(7.3-7.6 \mu \mathrm{g} \mathrm{m}^{-3}\right)$, and followed a similar pattern for the average levels of 4.1 and

$4314.2 \mu \mathrm{g} \mathrm{m}^{-3}$, respectively.

432 In the literature, OC is often expressed as organic material (OM). To calculate OM,

433 multiplication factors of 1.6 and 2.1 for OC have been recommended for urban and non-urban

434 aerosols, respectively (Turpin and Lim, 2001). In this study, the factor of 1.6 was used for calculating

435 the OM values (Table 7). Fairly low average levels of EC and OC were observed for each

436 site/campaign, i.e., ranging between $0.4-1.5$ and 2.3-4.2 $\mu \mathrm{g} \mathrm{m}^{-3}$, respectively (Table 7), which

437 correspond to an $\mathrm{OM}+\mathrm{EC}$ range of 4.1-7.7 $\mu \mathrm{g} \mathrm{m}^{-3}$. This interval is similar to those $\mathrm{OM}+\mathrm{EC}$ values,

438 reported for the total carbon content of $\mathrm{PM}_{2.5}$ in Ghent, Belgium (3.9-9.7 $\mu \mathrm{g} \mathrm{m}^{-3}$ ) (Viana et al., 2007)

439 and to those OC+EC ranges for North European cities (1-6 $\left.\mu \mathrm{g} \mathrm{m}^{-3}\right)$ (Querol et al., 2004), but a bit

440 lower than those reported for Central European cities (3-16 $\left.\mu \mathrm{g} \mathrm{m}^{-3}\right)$ (Querol et al., 2004; Putaud et al., 441 2004).

442 The two-hour peak values of EC and OC of 19 and $20 \mu \mathrm{g} \mathrm{m}{ }^{-3}$, respectively, were found at

443 Borgerhout (Table 8). A similar high OC value was found at Petroleumkaai in the first campaign;

444 whereas the EC value was lower $\left(7.4 \mu \mathrm{g} \mathrm{m}^{-3}\right)$. The highest two-hourly minimum value of EC was

445 observed in Borgerhout $\left(0.44 \mu \mathrm{g} \mathrm{m}^{-3}\right)$ in winter-spring, whereas the other sites yielded 1-2 orders of

446 magnitude lower values. Interestingly, the highest minimum OC values occurred in Mechelen $(1.1 \mu \mathrm{g}$

$\left.447 \mathrm{~m}^{-3}\right)$ and Hasselt $\left(0.86 \mu \mathrm{g} \mathrm{m}^{-3}\right)$, which are suburban areas (both influenced by industrial activities), 
448 though the less intense, but continuous local emissions by car and ship traffic may contribute to these

449 increased background OC levels.

\subsubsection{OC/EC ratios}

The primary $\mathrm{OC} / \mathrm{EC}$ ratio is defined as the atmospheric concentration of organic material

453 emitted directly into the air by anthropogenic sources and measured as primary OC divided by the 454 atmospheric level of EC. In early studies, a primary OC/EC value of 2.2 is assumed to indicate rising 455 secondary organic aerosol (SOA) levels in the atmosphere (Turpin and Huntzicker, 1991). An 456 OC/EC ratio of 2 has also been used to identify the formation of SOAs (Chow et al., 1996). A recent study by Harrison and Yin (2008) suggests a minimum OC/EC ratio of 0.65 .

$458 \quad$ For most of the sampling sites, a high OC/EC ratio (3.7-9) was generally observed (Table 7).

459 The exception was the heavy trafficked urban site of Borgerhout with a value of 1.9 in each 460 campaign. Especially high OC/EC ratios of 8.4 and 9 were observed at Mechelen and Hasselt, 461 respectively, the sites with medium-to-low traffic density and some industrial influence. The 462 experienced high OC/EC ratios indicate an intensive formation of SOAs or the contribution of local 463 sources to increase OC levels (e.g., wood burning).

465 3.4.3. Contribution of total carbon $(\mathrm{EC}+\mathrm{OC})$ to $\mathrm{PM}_{2.5}$ levels

466 The minimum levels of total carbon (TC) in $\mathrm{PM}_{2.5}$ ranged between 3 and $11 \%$, while its 467 maximum values were found to be between 22 and $77 \%$ (Table 9). The average contribution of TC 468 was relatively high for Petroleumkaai (32\%), Hasselt (23\%) and Mechelen (24\%), whereas the 469 remaining sites were usually below $14 \%$. Apart from the industrial site of Petroleumkaai, these 470 values are generally lower than those reported for the OM+EC content of $\mathrm{PM}_{2.5}$ for Ghent (32-39\%)

471 (Viana et al., 2007), as well as those reported for other European cities (20-45 \%) (Viana et al., 2007; 472 Putaud et al., 2004; Querol et al., 2004). 


\section{Conclusions}

The results obtained with the assistance of diverse physical and chemical characterisation methods for $\mathrm{PM}_{2.5}$ generally showed very similar temporal and spatial changes in the pattern of the studied aerosol components. The optical dust monitoring methods (e.g., Dustscan) produce higher $\mathrm{PM}_{2.5}$ mass readings than the gravimetric methods, consequently, they can only be used for showing concentration trends. The $\mathrm{PM}_{2.5}$ data from the standard TEOM monitoring are handicapped by sampling artifacts (e.g., evaporation losses), whereas values from the TEOM-FDMS method agreed well with the data from gravimetry. The monitoring over Flanders produced similar results for the $\mathrm{PM}_{2.5}$ mass as for other European sites. However, a fairly large difference was found for the elemental and total carbon (OC+EC) contributions in Flanders compared to higher percentages observed in most of the Central European cities. This bias might be due to the use of a standard ACPM in the present experiments, which is handicapped by lower EC/OC readings.

The metal content of $\mathrm{PM}_{2.5}$ indicated the high importance of industry-related emissions over Flanders and a lower impact of the traffic emission. PCA and correlation analysis showed the contribution of local traffic, heavy oil burning, combustion, and ferrous/non-ferrous industrial emission, as the main sources to $\mathrm{PM}_{2.5}$ levels. It is to be noted that only one of the sampling sites (Borgerhout with heavy traffic and some industrial influence) did not meet the EC's proposed annual limit for $\mathrm{PM}_{2.5}$. This is an indicative of "hot-spots" existing in the urban environment, which should be locally monitored for $\mathrm{PM}_{2.5}$ levels. Moreover, local legislations on the air quality assurance of these areas should be introduced for counteracting the pollution periods when the dust content is expectable to overtake the daily allowable EC-limit, for example, by immediate actions of local authorities (e.g., by reducing the density of the local traffic).

\section{Acknowledgement}

This study presents part of the results obtained in the project "Metingen van $\mathrm{PM}_{2.5}$ in Vlaanderen (2001-2003)", for which financial support by the Flemish Environment Agency (Vlaamse Milieumaatschappij) is gratefully acknowledged. One of the authors (L. Bencs) expresses his gratitude for the support by the Hungarian Scientific Research Fund (OTKA) under the project of 
$502 \quad$ F67647. 


\section{References}

Bosco, M.L., Varrica, D., Dongarra, G., 2005. Case study: inorganic pollutants associated with particulate matter from an area near a petrochemical plant. Environmental Research, 99, 18-30.

Bencs, L., Ravindra, K., de Hoog, J., Rasoazanany, E.O., Deutsch, F., Bleux, N., Berghmans, P., Roekens, E., Krata, A., Van Grieken, R., 2008. Mass and ionic composition of atmospheric fine particles over Belgium and their relation with gaseous air pollutants. Journal of Environmental Monitoring, 10, 1148-1157.

Charron, A., Harrison, R.M., Moorsroft, S., Booker, J., 2004. Quantitative interpretation of divergence between $\mathrm{PM}_{10}$ and $\mathrm{PM}_{2.5}$ mass measurement by TEOM and gravimetric (Partisol) instruments. Atmospheric Environment, 38, 415-423.

Chen, S.J., Hsieh, L.T., Tsai, C.C., Fang, G.C., 2003. Characterization of atmospheric $\mathrm{PM}_{10}$ and related chemical species in southern Taiwan during the episode days, Chemosphere, 53, 29-41.

Chow, J.C., Watson, J.G., Lu, Z.Q., Lowenthal, D.H., Frazier, C.A., Solomon, P.A., Thuillier, R.H., Magliano, K., 1996. Descriptive analysis of $\mathrm{PM}_{2.5}$ and $\mathrm{PM}_{10}$ at regionaly representative locations during SJVAQS/AUSPEX. Atmospheric Environment, 30, 2079-2112.

Costello, A.B., Osborne, J.W., 2005. Best practices in exploratory factor analysis: four recommendations for getting the most from your analysis. Practical Assessment Research \& Evaluation, 10, 1-9.

European Directive, 2008. Directive 2008/50/EC of the European Parliament and of the Council of 21 May 2008 on ambient air quality and cleaner air for Europe. Official Journal of the European Union, L152, 1-44.

Godoi, R.H.M., Godoi, A.F.L., Worobiec, A., Andrade, S.J., de Hoog, J., Santiago-Silva, M.R., Van Grieken, R., 2004. Characterisation of sugar cane combustion particles in the Araraquara region, Southeast Brazil. Microchimica Acta, 145, 53-56.

Harrison, R.M., Yin, J., 2008. Sources and processes affecting carbonaceous aerosol in central England. Atmospheric Environment, 42, 1413-1423.

Harrison, R.M., Jones, A.M., Lawrence, R.G., 2004. Major component composition of $\mathrm{PM}_{10}$ and $\mathrm{PM}_{2.5}$ from roadside and urban background sites. Atmospheric Environment, 38, 4531-4538.

Hjortenkrans, D.S.T., Bergbäck, B.G., Häggerud, A.V., 2007. Metal emissions from brake linings and tires: Case studies of Stocholm, Sweden 1995/1998 and 2005. Environmental Science and Technology, 41, 5225-5230.

Hoornaert, S., Godoi, R.H.M., Van Grieken, R., 2003. Single particle characterization of the aerosol in the marine boundary layer and free troposhphere over Tenerife, NE Atlantic, during ACE-2. Journal of Atmospheric Chemistry, 46, 271-293.

Hoornaert, S., Godoi, R.H.M., Van Grieken, R., 2004. Elemental and single particle aerosol characterization at a background station in Kazakhstan. Journal of Atmospheric Chemistry, 48, 301315 .

Heal, M.R., Hibbs, L.R., Agius, R.M., Beverland, I.J., 2005. Total and water-soluble trace metal content of urban background $\mathrm{PM}_{10}, \mathrm{PM}_{2.5}$ and black smoke in Edinburgh, UK. Atmospheric Environment, 39, 1417-1430.

Hu, S.-H., Herner, J.D., Shafer, M., Robertson, W., Schauer, J.J., Dwyer, H., Collins, J., Huai, T., Ayala, A., 2009. Metals emitted from heavy-duty diesel vehicles equipped with advanced PM and $\mathrm{NO}_{\mathrm{x}}$ emission controls. Atmospheric Environment, 43, 2950-2959. 
Intergovernmental Panel on Climate Change (IPCC), 2007. Climate Change 2007: "The Physical Science Basis" Contribution of Working Group I to the Fourth Assessment Report of the Intergovernmental Panel on Climate Change. Cambridge University Press, New York.

Keegan, T.J., Faragó, M.E., Thornton, I., Hong, B., Colvile, R.N., Pesch, B., Jakubis, P., Nieuwenhuijsen, M.J., 2006. Dispersion of As and selected heavy metals around a coal-burning power station in central Slovakia. Science of the Total Environment, 358, 61-71.

Lim, H.J., Turpin., B.J., 2002. Origins of primary and secondary organic aerosols in Atlanta: Results of Time-resolved measurements during the Atlanta Supersite Experiment. Environmental Science and Technology, 36, 4489-4496.

Maenhaut, W., Raes, N., De Backer, H., Cheymol, A., 2007. Seasonal variability in atmospheric aerosol levels and elemental compositions during 2006 at Uccle, Belgium, In: Proceedings of the XI. International Conference on PIXE and its Analytical Applications, Puebla Mexico, May 25-29, 2007.

Maenhaut, W., 2008. New Direction: future needs for global monitoring and research of aerosol composition. Atmospheric Environment, 42, 1070-1072.

Manoli, E., Voutsa D., Samara, C., 2002. Chemical characterization and source identification/apportionment of fine and coarse air particles in Thessaloniki, Greece. Atmospheric Environment, 36, 949-961.

Matsumoto, K., Hayano, T., Uematsu, M., 2003. Positive artifact in the measurement of particulate carbonaceous substances using an ambient carbon particulate monitor, Atmospheric Environment, 37, 4713-4717.

Nriagu, J.O., Pacyna, J.M., 1988. Quantitative assessment of worldwide contamination of air, water and soils by tracemetals, Nature, 333, 134-139.

Oravisjärvi, K., Timonen, K.L., Wiikinkoski, T., Ruuskanen, A.R., Heinänen, K., Ruuskanen, J., 2003. Source contributions to $\mathrm{PM}_{2.5}$ particles in the urban air of a town situated close to a steel works. Atmospheric Environment, 37, 1013-1022.

Pope, C.A., Dockery, D.W., 2006. Health Effects of Fine Particulate Air Pollution: Lines that Connect. Journal ofthe Air and Waste Management Association, 56, 709-742.

Putaud, J.P., Raes, F., Van Dingenen, R., Brüggemann, E., Facchini, M.C., Decesari, S., Fuzzi, S., Gehrig, R., Hüglin, C., Laj, P., Lorbeer, G., Maenhaut, W., Mihalopoulos, N., Müller, K., Querol, X., Rodriguez, S., Schneider, J., Spindler, G., ten Brink, H., Tørseth, K., Wiedensohler, A., 2004. A European aerosol phenomenology - 2: chemical characteristics of particulate matter at kerbside, urban, rural and background sites in Europe. Atmospheric Environment, 38, 2579-2595.

Querol, X., Alastuey, A., Ruiz, C.R., Artiñano, B., Hansson, H.C., Harrison, R.M., Buringh, E., ten Brink, H.M., Lutz, M., Bruckmann, P., Straehl, P., Schneider, J., 2004. Speciation and origin of PM10 and PM2.5 in selected European cities. Atmospheric Environment, 38, 6547-6555.

Pio, C.A., Nunes, T.V., Borrego, C.A., Martins, J., 1989. Assessment of air pollution sources in an industrial atmosphere using principal component/multilinear regression analysis. Science of the Total Environment, 80, 279-292.

Ravindra, K., Stranger, M., Van Grieken, R., 2008. Chemical characterization and multivariate analysis of atmospheric $\mathrm{PM}_{2.5}$ particles. Journal of Atmospheric Chemistry, 59, 199-218.

Samek, L., Injuk, J., Van Espen, P., Van Grieken, R., 2002. Performance of a new compact EDXRF spectrometer for aerosol analysis. X-Ray Spectrometry, 31, 83-86. 
618 ten Brink, H., Hoek, G., Khlystov, A., 2005. An approach to monitor the elemental carbon in the 619 ultrafine aerosol. Atmospheric Environment, 39, 6255-6259.

Turpin, B.J., Huntzicker, J.J., 1991. Secondary formation of organic aerosol in the Los Angeles basin: a descriptive analysis of organic and elementary carbon concentrations. Atmospheric Environment, 25A, 207-215.

Turpin, B.J., Lim, H.J., 2001. Species contributions to PM2.5 mass concentrations: Revisiting common assumptions for estimating organic mass. Aerosol Science and Technology, 35, 602-610.

Twomey, S., 1974. Pollution and planetary albedo. Atmospheric Environment, 8, 1251-1256.

Vallius, M., Janssen, N.A.H., Heinrich, J., Hoek, G., Ruuskanen, J., Cyrys, J., Van Grieken, R., de Hartog, J.J., Kreyling, W.G., Pekkanen, J., 2005. Sources and elemental composition of ambient $\mathrm{PM}_{2.5}$ in three European cities. Science of the Total Environment, 337, 147-162.

Vecchi, R., Valli, G., Fermo, P., D’Alessandro, A., Piazzalunga, A., Bernardoni, V., 2009. Organic and inorganic sampling artefacts assessment. Atmospheric Environment, 43, 1713-1720.

Vekemans, B., Janssens, K., Vincze, L., Adams, F., Van Espen, P., 1994. Analysis of X-ray spectra by iterative least squares (AXIL): new developments. X-Ray Spectrometry, 23, 278-285.

Viana, M., Maenhaut, W., Chi, X., Querol, X., Alstuey, A., 2007. Comparative chemical mass closure of fine and coarse aerosols at two sites in south and west Europe: Implications for EU air pollution policies, Atmospheric Environment, 41, 315-326.

Wang, Y.F., Huang, K.L., Li, C.T., Mi, H.H., Luo, J.H., Tsai, P.J., 2003. Emissions of fuel metals content from a diesel vehicle engine, Atmospheric Environment, 4637-4643. 647 W., Vallius, M., Szidat, S., Prévôt, A.S.H., Hueglin, C., Bloemen, H., Wåhlin, P., Vecchi, R., 648 Miranda, A.I., Kasper-Giebl, A., Maenhaut, W., Hitzenberger, R., 2008. Source apportionment of 
Table 1. Time schedule of the sampling campaigns and average daily meteorological data with their variations (expressed as standard deviation - SD)

\begin{tabular}{|c|c|c|c|c|c|c|c|c|c|}
\hline $\begin{array}{l}\text { Location - } \\
\text { campaign }\end{array}$ & $\begin{array}{l}\text { Sampling period } \\
\text { (day/month/year) }\end{array}$ & Season & $\begin{array}{c}\text { Average } \\
\text { precipitation } \\
\left.(\text { mm day })^{-1}\right)\end{array}$ & $\begin{array}{c}\text { Air } \\
\text { temperature } \\
\left({ }^{\circ} \mathrm{C}\right)\end{array}$ & $\begin{array}{c}\text { Air pressure } \\
(\mathrm{hPa})\end{array}$ & $\begin{array}{c}\text { Relative } \\
\text { humidity (\%) }\end{array}$ & $\begin{array}{l}\text { Wind } \\
\text { speed } \\
\left(\mathrm{m} \mathrm{s}^{-1}\right)\end{array}$ & $\begin{array}{l}\text { Main wind } \\
\text { direction* }\end{array}$ & $n$ \\
\hline Petroleumkaai-1 & 18/09/2001-29/10/2001 & A & $3.0 \pm 6.0$ & $14.9 \pm 1.8$ & $1014 \pm 7$ & $72 \pm 5$ & $3.9 \pm 1.4$ & SW & 36 \\
\hline Petroleumkaai-2 & $19 / 12 / 2002-23 / 02 / 2003$ & W & $3.5 \pm 5.9$ & $4.5 \pm 4.6$ & $1013 \pm 13$ & $73 \pm 7$ & $4.4 \pm 1.4$ & S-SW/NE & 52 \\
\hline Borgerhout-1 & 06/11/2001-10/12/2001 & $\mathrm{A}-\mathrm{W}$ & $2.7 \pm 4.7$ & $6.9 \pm 3.2$ & $1024 \pm 11$ & $75 \pm 5$ & $3.6 \pm 1.6$ & SW & 32 \\
\hline Borgerhout-2 & $10 / 02 / 2003-07 / 04 / 2003$ & $\mathrm{~W}-\mathrm{Sp}$ & $0.9 \pm 1.8$ & $7.1 \pm 3.9$ & $1024 \pm 8$ & $59 \pm 10$ & $3.4 \pm 1.3$ & E/E-NE/SE & 45 \\
\hline Hasselt-1 & $01 / 02 / 2002-26 / 03 / 2002$ & W-Sp & $3.2 \pm 4.3$ & $8.2 \pm 3.0$ & $1010 \pm 9$ & $67 \pm 7$ & $5.5 \pm 2.1$ & SW/W-SW & 46 \\
\hline Hasselt-2 & 27/09/2002-04/11/2002 & A & $2.1 \pm 3.0$ & $11.5 \pm 2.1$ & $1013 \pm 9$ & $70 \pm 6$ & $4.0 \pm 1.9$ & SW/W & 38 \\
\hline Mechelen-1 & $16 / 05 / 2002-26 / 06 / 2002$ & $\mathrm{Sp}-\mathrm{Su}$ & $2.1 \pm 5.1$ & $17.1 \pm 2.6$ & $1014 \pm 7$ & $60 \pm 6$ & $3.7 \pm 0.9$ & SW & 30 \\
\hline Mechelen-2 & 05/11/2002-03/01/2003 & A-W & $2.6 \pm 4.0$ & $6.2 \pm 4.2$ & $1012 \pm 11$ & $74 \pm 7$ & $3.8 \pm 1.4$ & S/SE/E & 38 \\
\hline Wingene-1 & $27 / 03 / 2002-15 / 05 / 2002$ & $\mathrm{Sp}$ & $1.3 \pm 2.3$ & $10.2 \pm 2.5$ & $1016 \pm 9$ & $73 \pm 10$ & $4.1 \pm 1.8$ & SW/N/N-NE & 41 \\
\hline Wingene-2 & $27 / 06 / 2002-12 / 08 / 2002$ & $\mathrm{Su}$ & $2.2 \pm 5.0$ & $17.2 \pm 2.6$ & $1014 \pm 5$ & $79 \pm 6$ & $3.6 \pm 1.1$ & SW/W/NW & 45 \\
\hline
\end{tabular}

Abbreviations: A -autumn, $\mathrm{W}$ - winter, $\mathrm{Sp}$ - spring, Su - summer,

$\mathrm{n}-$ the number of daily data used for calculating average concentrations

* - the main wind directions were extracted from the windrose of each site/campaign 
Table 2. Daily average $\mathrm{PM}_{2.5}$-data $\left(\mu \mathrm{g} \mathrm{m}^{-3}\right)$ from standard TEOM units

\begin{tabular}{lcccccc}
\hline Location & \multicolumn{3}{c}{ Campaign 1 } & \multicolumn{3}{c}{ Campaign 2 } \\
& Min & Max & Mean \pm SD & Min & Max & Mean $\pm S D$ \\
\hline Petroleumkaai & 8.2 & 30.8 & $17 \pm 6$ & 8.3 & 31.9 & $16 \pm 6$ \\
Borgerhout & 6.2 & 34.9 & $20 \pm 8$ & 12.0 & 47.0 & $28 \pm 11$ \\
Zelzate & 6.2 & 53.1 & $21 \pm 11$ & 5.7 & 30.1 & $16 \pm 7$ \\
Hasselt & 6.8 & 34.4 & $13 \pm 6$ & 6.8 & 30.8 & $15 \pm 6$ \\
Wingene & 6.5 & 45.1 & $20 \pm 10$ & 6.5 & 27.2 & $13 \pm 5$ \\
Mechelen & 7.4 & 26.7 & $14 \pm 5$ & 9.9 & 44.5 & $21 \pm 9$ \\
Mechelen & 8.0 & 27.0 & $13 \pm 4$ & $8.0^{\mathrm{a}}$ & $51.0^{\mathrm{a}}$ & $22 \pm 10^{\mathrm{a}}$ \\
\hline
\end{tabular}

Table 3. Daily $\mathrm{PM}_{2.5}$-data $\left(\mu \mathrm{g} \mathrm{m}^{-3}\right.$ ) from Partisol sampling and gravimetry (Teflon filters)

\begin{tabular}{lcccccc}
\hline Location & \multicolumn{3}{c}{ Campaign 1 } & \multicolumn{3}{c}{ Campaign 2 } \\
& Min & Max & Mean \pm SD & Min & Max & Mean \pm SD \\
\hline Petroleumkaai & 7.9 & 59.5 & $20 \pm 11$ & 6.3 & 61.6 & $21 \pm 12$ \\
Borgerhout & 0.2 & 62.7 & $29 \pm 15$ & 13.8 & 99.7 & $45 \pm 22$ \\
Zelzate & 1.6 & 67.7 & $26 \pm 16$ & 5.9 & 43.8 & $16 \pm 8$ \\
Hasselt & 5.5 & 59.0 & $19 \pm 13$ & 4.4 & 38.5 & $16 \pm 8$ \\
Wingene & 7.0 & 63.9 & $28 \pm 16$ & 5.2 & 23.2 & $11 \pm 4$ \\
Mechelen & 7.1 & 21.3 & $12 \pm 7$ & 9.2 & 60.1 & $24 \pm 13$ \\
& & & & & & \\
\hline
\end{tabular}


Table 4. Average $\mathrm{PM}_{2.5}$ concentrations for the monitoring period and extrapolated annual values

\begin{tabular}{lccc}
\hline Location & $\begin{array}{c}\text { Number } \\
\text { of days } \\
\text { sampled }\end{array}$ & $\boldsymbol{P M}_{2.5}$ average $\left(\boldsymbol{\mu g} \boldsymbol{m}^{-3}\right)$ \\
\cline { 3 - 4 } & & $\begin{array}{c}\text { Monitored } \\
\text { with Partisol }\end{array}$ & $\begin{array}{c}\text { Extrapolated } \\
\text { yearly }\end{array}$ \\
Petroleumkaai & 89 & 21 & 23 \\
Borgerhout & 76 & 38 & 29 \\
Zelzate & 91 & 22 & 21 \\
Hasselt & 82 & 17 & 20 \\
Wingene & 94 & 20 & 18 \\
Mechelen & 71 & 19 & 19 \\
\hline
\end{tabular}

Table 5. Percentage of $\mathrm{PM}_{2.5}$ due to elemental fraction (\%)

\begin{tabular}{lcccccc}
\hline Location & \multicolumn{3}{c}{ Campaign - 1 } & \multicolumn{3}{l}{ Campaign - 2 } \\
\hline & Min & Max & Mean \pm SD & Min & Max & Mean \pm SD \\
& & & & & & \\
Petroleumkaai & 2.4 & 10.9 & $6.3 \pm 2.5$ & 1.1 & 11.5 & $2.7 \pm 2.0$ \\
Borgerhout & 1.1 & 7.5 & $2.9 \pm 1.2$ & 0.9 & 4.0 & $2.2 \pm 0.7$ \\
Zelzate & 0.7 & 24.1 & $5.8 \pm 5.5$ & 1.0 & 12.9 & $4.0 \pm 2.5$ \\
Hasselt & 0.2 & 5.1 & $2.1 \pm 1.1$ & 1.8 & 14.6 & $4.3 \pm 3.2$ \\
Wingene & 0.4 & 6.3 & $2.1 \pm 1.4$ & 0.8 & 4.1 & $2.1 \pm 0.8$ \\
Mechelen & 0.1 & 15.1 & $2.8 \pm 2.6$ & 1.1 & 13.5 & $3.8 \pm 2.8$ \\
\hline
\end{tabular}

SD - standard deviation 
Table 6. Average elemental concentrations in $\mathrm{PM}_{2.5}$ over various sites and campaigns

\begin{tabular}{|c|c|c|c|c|c|c|c|c|c|c|c|c|c|c|c|c|}
\hline \multirow[t]{2}{*}{ Location-campaign } & \multirow[t]{2}{*}{ Season } & \multicolumn{14}{|c|}{ Average concentration $\left(\mathrm{ng} \mathrm{m}^{-3}\right)$} & \multirow[b]{2}{*}{ Tota } \\
\hline & & $\mathbf{K}$ & $\mathbf{C a}$ & $\mathbf{T i}$ & $\mathbf{V}$ & $\mathrm{Cr}$ & Mn & $\mathbf{F e}$ & $\mathbf{N i}$ & $\mathbf{C u}$ & $\mathbf{Z n}$ & $\mathbf{R b}$ & $\mathbf{P b}$ & Al & $\mathbf{S i}$ & \\
\hline Petroleumkaai-1 & A & 122 & 104 & 11 & 9 & 2 & 9 & 188 & 6 & 6 & 57 & n.d. & 13 & 122 & 366 & 1015 \\
\hline Petroleumkaai-2 & $\mathrm{W}$ & 139 & 3 & 5 & 16 & 1 & 4 & 66 & 7 & 4 & 31 & 1 & 26 & 83 & 58 & 444 \\
\hline Borgerhout-1 & A-W & 175 & 79 & 2 & 5 & 2 & 11 & 197 & 8 & 10 & 70 & n.d. & 28 & 55 & 186 & 828 \\
\hline Borgerhout-2 & $\mathrm{W}-\mathrm{Sp}$ & 269 & 78 & 8 & 9 & 3 & 10 & 253 & 6 & 13 & 83 & 2 & 49 & 106 & 118 & 1007 \\
\hline Zelzate-1 & $\mathrm{W}$ & 247 & 111 & 6 & 6 & 1 & 13 & 279 & 9 & 7 & 84 & 1 & 24 & 60 & 302 & 1151 \\
\hline Zelzate-2 & $\mathrm{Su}-\mathrm{A}$ & 104 & 63 & 6 & 8 & 1 & 3 & 95 & 4 & 5 & 20 & 1 & 15 & 51 & 181 & 557 \\
\hline Hasselt-1 & W-Sp & 93 & 32 & 2 & n.d. & n.d. & 4 & 56 & 3 & 3 & 33 & n.d. & 8 & 21 & 74 & 329 \\
\hline Hasselt-2 & A & 239 & 91 & 3 & 4 & 3 & 8 & 144 & 9 & 7 & 65 & 2 & 26 & 55 & 42 & 698 \\
\hline Mechelen-1 & $\mathrm{Sp}-\mathrm{Su}$ & 69 & 34 & 1 & 1 & 2 & 5 & 60 & 4 & 5 & 31 & 1 & 8 & 29 & 74 & 324 \\
\hline Mechelen-2 & A-W & 183 & 91 & 3 & 3 & 3 & 9 & 127 & 8 & 9 & 66 & 2 & 30 & 46 & 35 & 615 \\
\hline Wingene-1 & $\mathrm{Sp}$ & 85 & 21 & 1 & 7 & 1 & 4 & 57 & 3 & 2 & 22 & 2 & 13 & 34 & 66 & 318 \\
\hline Wingene-2 & $\mathrm{Su}$ & 66 & 20 & 1 & 5 & 1 & 3 & 31 & 3 & 1 & 14 & 1 & 10 & 28 & 38 & 222 \\
\hline Overall average & - & 149 & 61 & 4 & 7 & 2 & 7 & 129 & 6 & 6 & 48 & 1.4 & 21 & 58 & 128 & 626 \\
\hline SD & - & 72 & 37 & 3 & 4 & 1 & 3 & 83 & 2 & 3 & 25 & 1 & 12 & 32 & 110 & 315 \\
\hline
\end{tabular}

Abbreviations: A - autumn; W - winter; Sp - spring; Su - summer; n.d. - not detected 
Table 7. Daily concentrations of EC and OC, and related OM and OC/EC ratios

\begin{tabular}{|c|c|c|c|c|c|c|c|c|c|c|}
\hline \multirow[t]{2}{*}{ Location - campaign } & \multirow[t]{2}{*}{ Season } & \multicolumn{3}{|c|}{$E C\left(\mu g^{-3}\right)$} & \multicolumn{3}{|c|}{$\mathrm{OC}\left(\mu \mathrm{g} \mathrm{m}^{-3}\right)$} & \multirow{2}{*}{$\begin{array}{c}\text { OC/EC } \\
\text { Mean }\end{array}$} & \multirow{2}{*}{$\begin{array}{l}\mathbf{O M}^{*} \\
\text { Mean }\end{array}$} & \multirow{2}{*}{$\begin{array}{c}\mathbf{O M}+\mathbf{E C} \\
\text { Mean }\end{array}$} \\
\hline & & Min & Max & Mean \pm SD & Min & $\operatorname{Max}$ & Mean \pm SD & & & \\
\hline Petroleumkaai - 1 & A & 0.2 & 3.3 & $1.1 \pm 0.8$ & 2.0 & 7.3 & $4.1 \pm 1.3$ & 3.7 & 6.6 & 7.7 \\
\hline Petroleumkaai - 2 & W & 0.1 & 1.1 & $0.4 \pm 0.3$ & 0.7 & 7.6 & $2.3 \pm 1.3$ & 5.8 & 3.7 & 4.1 \\
\hline Borgerhout - 1 & $\mathrm{~A}-\mathrm{W}$ & 0.1 & 4.4 & $1.3 \pm 1.0$ & 1.3 & 4.9 & $2.5 \pm 1.1$ & 1.9 & 4.0 & 5.3 \\
\hline Borgerhout - 2 & Wi-Sp & 0.5 & 3.1 & $1.5 \pm 0.6$ & 1.0 & 5.6 & $2.9 \pm 1.3$ & 1.9 & 4.6 & 6.1 \\
\hline Zelzate - 1 & W & 0.0 & 1.9 & $0.6 \pm 0.5$ & 1.1 & 5.9 & $2.6 \pm 1.5$ & 6.5 & 4.2 & 4.8 \\
\hline Hasselt - 2 & A & 0.1 & 1.1 & $0.3 \pm 0.2$ & 1.3 & 5.6 & $2.7 \pm 1.1$ & 9.0 & 4.3 & 4.6 \\
\hline Mechelen - 2 & A-W & 0.1 & 1.5 & $0.5 \pm 0.3$ & 2.0 & 10.2 & $4.2 \pm 1.6$ & 8.4 & 6.7 & 7.2 \\
\hline
\end{tabular}

Abbreviations: A - autumn; W - winter; Sp - spring; SD - standard deviation;

* OM was calculated with a multiplication factor of 1.6 
Table 8. Minimum and maximum concentrations of EC and OC measured by the ACPM (2-hour data)

\begin{tabular}{lcccc}
\hline Location - campaign & \multicolumn{2}{c}{$\mathbf{E C}\left(\mu \mathbf{g ~ m}^{-3}\right)$} & \multicolumn{2}{c}{$\mathbf{O C}\left(\mu \mathbf{g ~ m}^{-3}\right)$} \\
\hline & Min. & Max. & Min. & Max. \\
& & & & \\
Petroleumkaai - 1 & 0.014 & 7.42 & 0.014 & 18.5 \\
Petroleumkaai - 2 & 0.025 & 1.72 & 0.391 & 8.75 \\
Borgerhout - 1 & 0.001 & 19.2 & 0.001 & 19.9 \\
Borgerhout - 2 & 0.444 & 5.05 & 0.465 & 10.3 \\
Zelzate - 1 & 0.001 & 9.22 & 0.001 & 12.3 \\
Hasselt - 2 & 0.006 & 3.09 & 0.858 & 8.06 \\
Mechelen - 2 & 0.061 & 1.91 & 1.15 & 13.5 \\
\hline
\end{tabular}

Table 9. Percentage of the $\mathrm{PM}_{2.5}$ concentration due to total carbon (EC+OC)

\begin{tabular}{|c|c|c|c|c|c|c|}
\hline \multirow[b]{2}{*}{ Location } & \multicolumn{3}{|c|}{ Campaign - 1} & \multicolumn{3}{|c|}{ Campaign - 2} \\
\hline & Min & $\operatorname{Max}$ & Mean \pm SD & Min & $\operatorname{Max}$ & Mean \pm SD \\
\hline Zelzate & 3 & 77 & $14 \pm 17$ & - & - & - \\
\hline Hasselt & - & - & - & 11 & 49 & $23 \pm 8$ \\
\hline Mechelen & - & - & - & 7 & 71 & $24 \pm 13$ \\
\hline Petroleumkaai & 9 & 48 & $32 \pm 8$ & 8 & 23 & $14 \pm 4$ \\
\hline Borgerhout & 8 & 48 & $14 \pm 8$ & 4 & 22 & $12 \pm 4$ \\
\hline
\end{tabular}




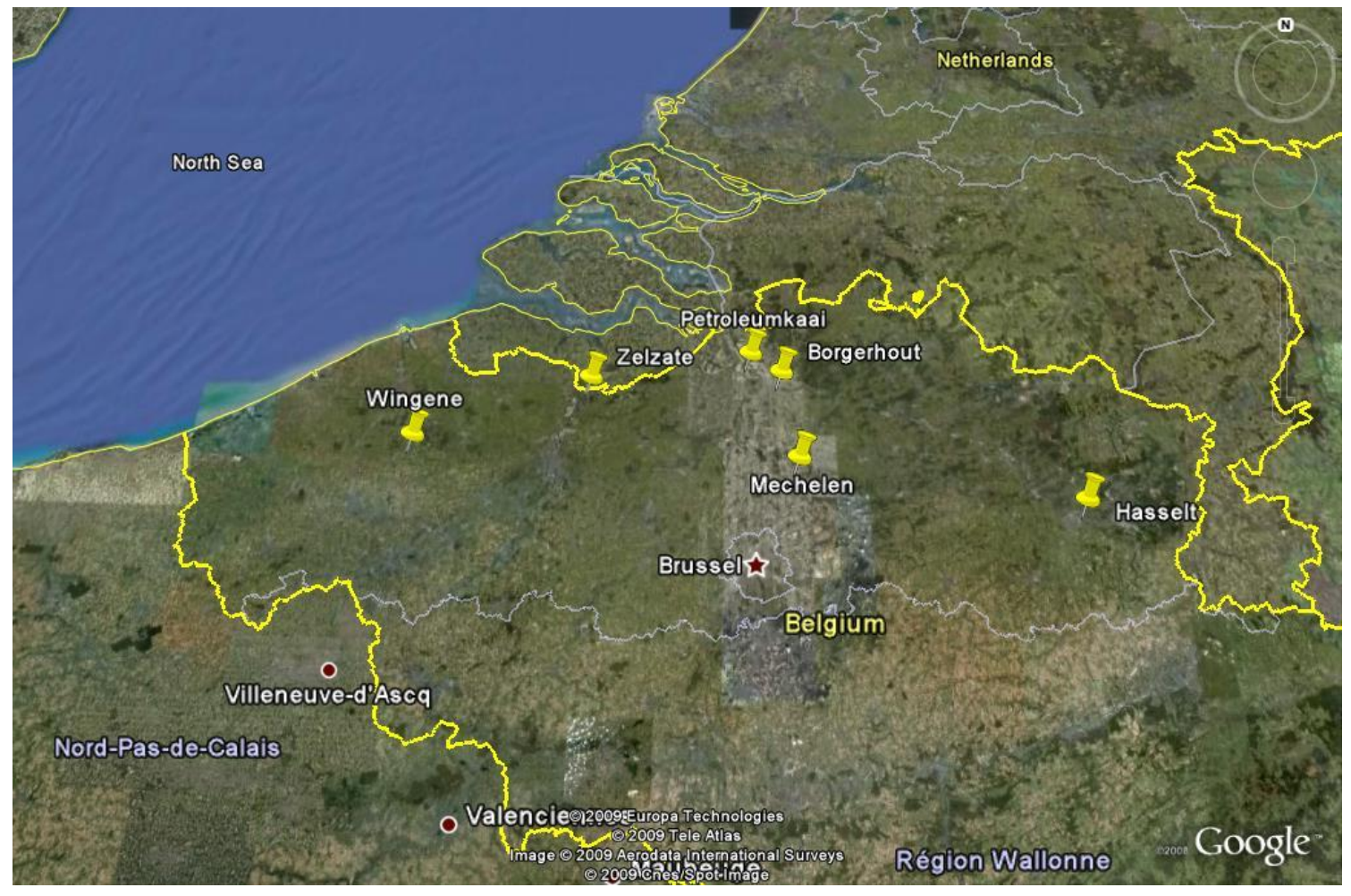

Fig. 1. Map of Flanders showing the six sampling sites 


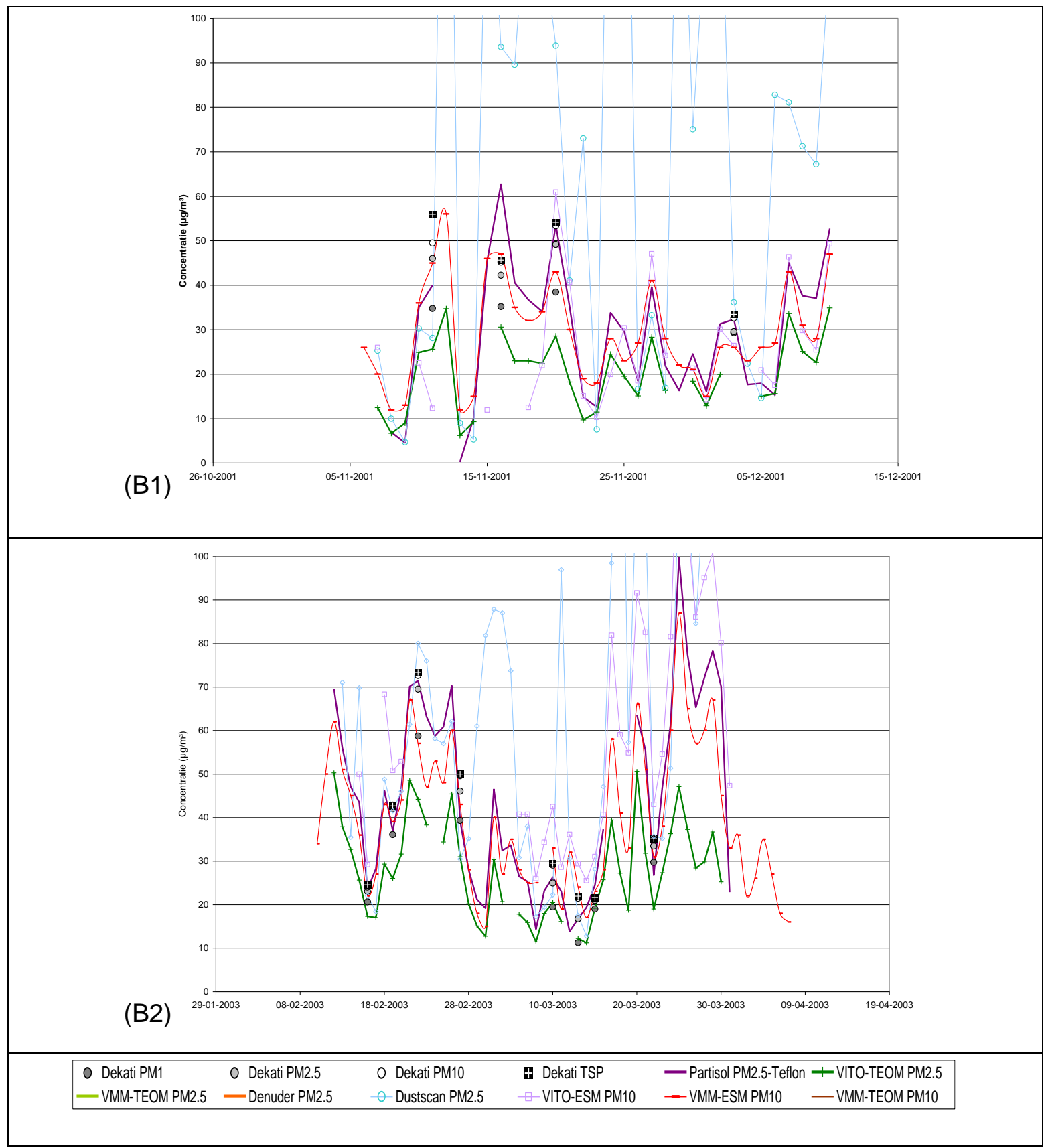

Fig. 2. Temporal variation of PM-concentrations in Borgerhout in campaign 1 (B1) and campaign 2 (B2) obtained with various methods 


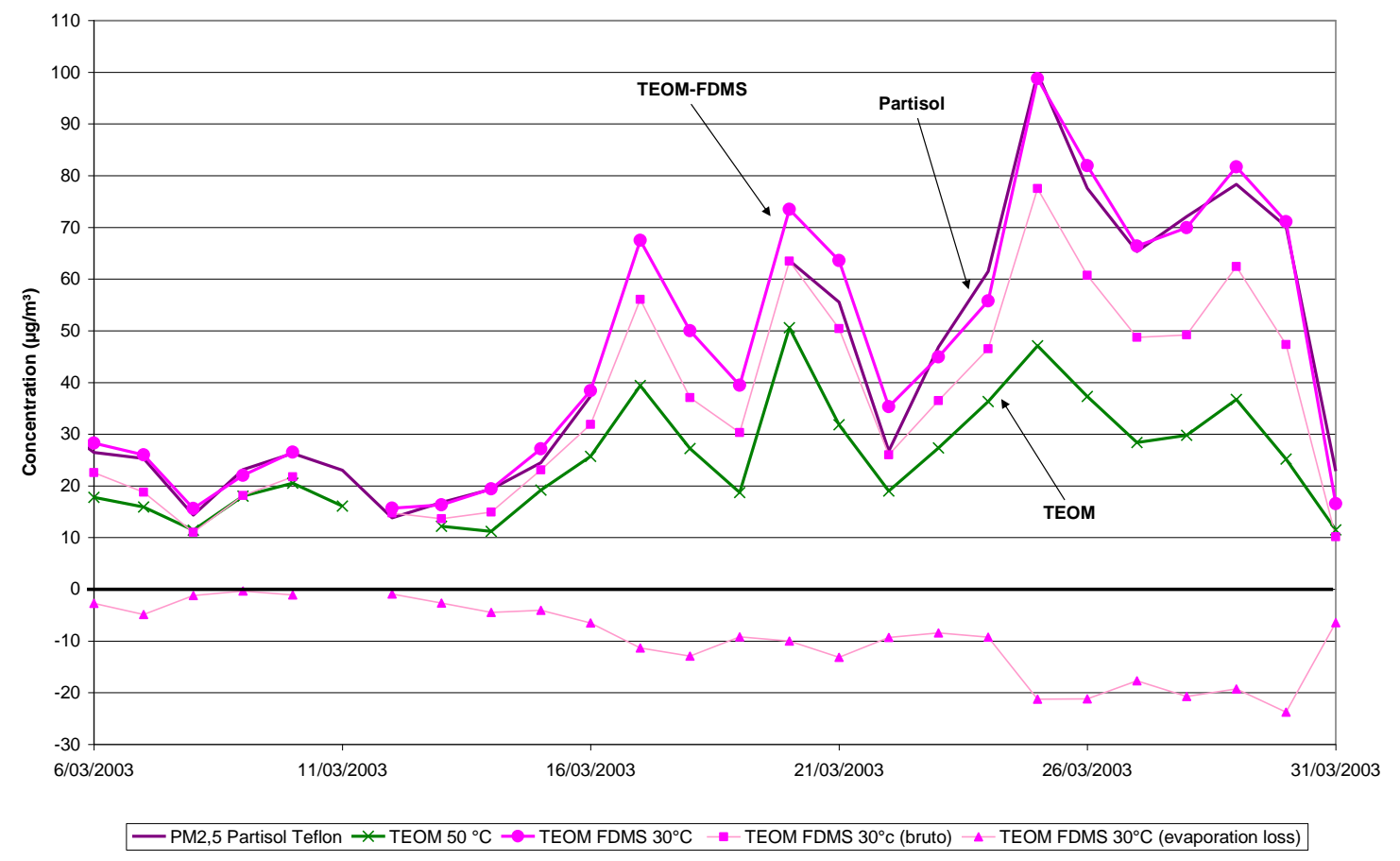

Fig. 3. Comparison of TEOM, TEOM-FDMS and Partisol sampling with gravimetry for the mass of $\mathrm{PM}_{2.5}$ aerosols at Borgerhout in campaign 2 (bruto: the mass at $30{ }^{\circ} \mathrm{C}$ obtained after correction with the evaporation loss) 


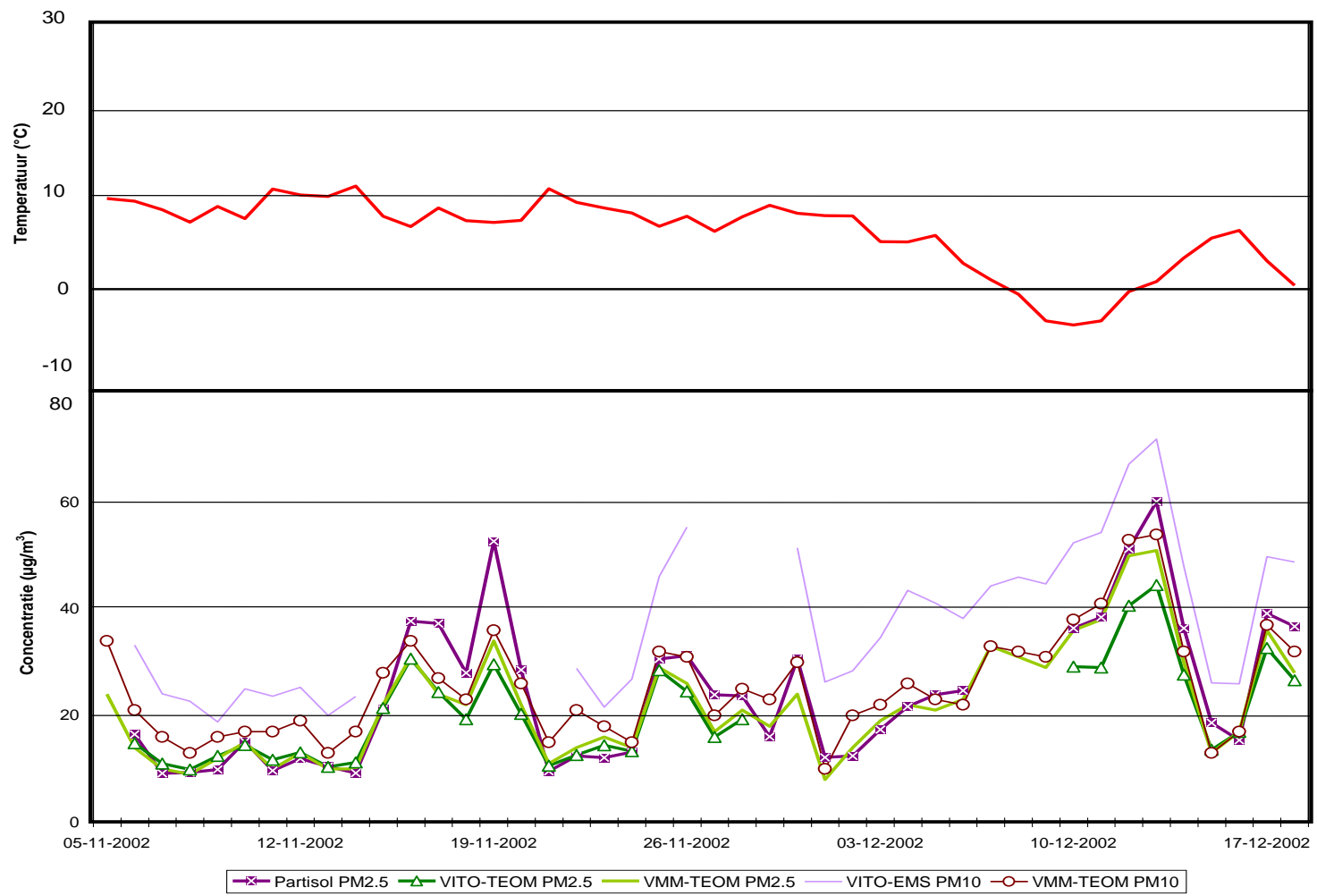

Fig. 4. Temporal fluctuation of the $\mathrm{PM}_{2.5}$ and $\mathrm{PM}_{10}$ mass fractions and the average daily temperature in the second campaign in Mechelen 


\section{Supplementary Material}

Supplementary Table 1

Correlation of PM elemental content, elemental and organic carbon, and meteorological parameters at various sampling sites and campaigns

\begin{tabular}{|c|c|c|c|c|c|c|c|c|c|c|c|c|}
\hline & $Z 1$ & $Z 2$ & $B 1$ & $B 2$ & $P 1$ & $P 2$ & $H 1$ & $H 2$ & $M 1$ & $M 2$ & $W 1$ & $W 2$ \\
\hline $\mathrm{PM}_{2.5}$ & $\begin{array}{l}\text { EC, OC, } \\
\text { TC, } \\
\text { RH(a), } \\
\text { PR(a), } \\
\text { T(a), } \\
\text { WS(a), } \mathbf{P}_{\mathrm{a}}\end{array}$ & $\mathbf{T}_{\mathrm{a}}, \mathbf{E C}$ & $\begin{array}{l}\text { EC, PR(a), } \\
\text { T(a), } \\
\text { WS(a), } \mathbf{P}_{\mathbf{a}}\end{array}$ & $\begin{array}{l}\text { EC, OC, } \\
\text { TC, } \\
\text { RH(a), } \\
\text { PR(a), T } \\
\text { P }_{\mathbf{a}} \text { (a), } \\
\mathbf{W S}(\mathbf{a})\end{array}$ & $\begin{array}{l}\mathbf{E C}, \mathbf{O C}, \\
\text { TC, RH, } \\
\mathrm{T}_{\mathrm{a}}(\mathrm{a}), \mathbf{W S}(\mathbf{a})\end{array}$ & $\begin{array}{l}\text { EC, OC, } \\
\text { TC, } \\
\text { RH(a), } \\
\operatorname{PR}(\mathbf{a}), \\
\mathbf{T}_{\mathbf{a}}(\mathbf{a}), \mathbf{P}_{\mathrm{a}}\end{array}$ & $\begin{array}{l}\text { EC, } \\
\mathrm{RH}(\mathrm{a}), \\
\mathbf{P R}(\mathbf{a}), \\
\mathbf{T}_{\mathrm{a}}(\mathbf{a}), \mathbf{P}_{\mathrm{a}}, \\
\mathbf{W S}(\mathbf{a})\end{array}$ & $\begin{array}{l}\text { EC, OC, } \\
\text { TC, RH, } \\
\text { PR(a), } \\
\mathrm{T}_{\mathrm{a}}(\mathrm{a}), \mathbf{P}_{\mathrm{a}}, \\
\mathbf{W S}(\mathbf{a})\end{array}$ & $\begin{array}{l}\mathrm{PR}, \mathbf{T}_{\mathbf{a}}(\mathbf{a}), \\
\mathrm{P}_{\mathrm{a}}(\mathrm{a})\end{array}$ & $\begin{array}{l}\text { EC, } \\
\mathrm{RH}(\mathrm{a}), \\
\operatorname{PR}(\mathrm{a}), \\
\mathbf{T}_{\mathbf{a}}(\mathbf{a}), \mathbf{P}_{\mathbf{a}}, \\
\mathbf{W S}(\mathbf{a})\end{array}$ & $\begin{array}{l}\text { RH(a), } \\
\text { P }_{\text {a' }} \\
\text { WS(a) }\end{array}$ & $\mathbf{E C}, \mathbf{T}_{\mathbf{a}}, \mathrm{P}_{\mathrm{a}}$ \\
\hline $\mathrm{PM}_{10}$ & $\begin{array}{l}\text { EC, OC, } \\
\text { TC, } \\
\text { RH(a), } \\
\text { PR(a), } \\
\mathrm{T}_{\mathrm{a}}(\mathrm{a}), \\
\mathbf{W S}(\mathbf{a}), \mathbf{P}_{\mathrm{a}}\end{array}$ & T, RH, EC & - & $\begin{array}{l}\text { EC, OC, } \\
\text { TC, } \\
\text { RH(a), } \\
\text { PR(a), T }, \\
\text { WS(a) }\end{array}$ & $\begin{array}{l}\text { EC, TC, } \\
\text { RH, } \mathrm{T}_{\mathrm{a}}(\mathrm{a}), \\
\mathrm{P}_{\mathrm{a}}, \mathbf{W S}(\mathbf{a})\end{array}$ & $\begin{array}{l}\text { EC, OC, } \\
\text { TC, } \\
\text { RH(a), } \\
\text { PR(a), } \\
\mathbf{T}_{\mathbf{a}}(\mathbf{a}), \mathbf{P}_{\mathbf{a}}\end{array}$ & $\begin{array}{l}\text { EC, } \\
\text { RH(a), } \\
\operatorname{PR}(\mathbf{a}), \\
\text { T }_{\mathrm{a}}(\mathbf{a}), \mathbf{P}_{\mathrm{a}}, \\
\mathbf{W S}(\mathbf{a})\end{array}$ & $\begin{array}{l}\text { EC, OC, } \\
\text { TC, } \mathbf{T}_{\mathrm{a}}, \mathbf{P}_{\mathrm{a}}, \\
\mathrm{WS}(\mathbf{a})\end{array}$ & PR(a) & $\begin{array}{l}\text { EC, } \\
\text { RH(a), } \\
\text { PR(a), } \\
\text { T }_{\mathbf{a}}(\mathbf{a}), \mathbf{P}_{\mathbf{a}}, \\
\text { WS(a) }\end{array}$ & - & $\begin{array}{l}\mathbf{E C}, \mathrm{RH}(\mathrm{a}), \\
\mathbf{T}_{\mathbf{a}}\end{array}$ \\
\hline $\mathrm{K}$ & $\begin{array}{l}\mathrm{Al}, \mathbf{S i}, \mathbf{P}, \\
\mathrm{S}, \mathrm{Cl}, \mathrm{Ca}, \\
\mathrm{Mn}, \mathbf{N i}, \\
\mathrm{Cu}, \mathrm{Zn}, \\
\mathrm{Br}, \mathrm{Sr}, \mathbf{P b}, \\
\text { EC,OC, } \\
\text { TC }\end{array}$ & $\begin{array}{l}\text { Al, Si, Ca, } \\
\text { V, Mn, Fe, } \\
\mathrm{Cu}, \mathbf{Z n}, \\
\text { Rb, Pb, Ta }\end{array}$ & $\begin{array}{l}\text { Al, Si, P, } \\
\text { S, Cl, Ca, } \\
\text { V, Mn, Fe, } \\
\text { Cu, Zn, } \\
\text { Br, Rb, } \\
\text { Pb, EC, } \\
\text { OC, TC, } \\
\text { WS(a) }\end{array}$ & $\begin{array}{l}\text { Al, Cr, } \\
\text { Mn, Fe, } \\
\text { Ni, Cu, } \\
\text { Zn, Rb, } \\
\text { Pb, EC, } \\
\text { OC, TC, } \\
\text { RH(a), } \\
\text { PR(a), } \\
\text { WS(a) }\end{array}$ & $\begin{array}{l}\text { Al, Si, P, S, } \\
\text { Ca, Mn, Fe, } \\
\text { Ni, Cu, Zn, } \\
\text { Rb, Pb, EC, } \\
\text { OC, TC, } \\
\text { WS(a) }\end{array}$ & $\begin{array}{l}\text { Mn, Fe, } \\
\text { Cu, Zn, } \\
\text { Rb, Pb, } \\
\text { EC, OC, } \\
\text { TC, PR(a), } \\
T_{a}(a), P_{a}, \\
\text { WS(a) }\end{array}$ & $\begin{array}{l}\mathrm{Al}, \mathrm{Si}, \mathbf{P}, \\
\mathrm{S}, \mathrm{Cl}, \mathrm{Ca}, \\
\mathrm{Mn}, \mathrm{Ni}, \\
\mathrm{Cu}, \mathrm{Zn}, \\
\mathrm{Br}, \mathrm{Pb}, \\
\mathrm{PM}_{2.5}\end{array}$ & $\begin{array}{l}\text { Al, Ca, } \\
\text { Mn, Ni, } \\
\text { Cu, Rb, } \\
\text { Sr, RH }\end{array}$ & $\begin{array}{l}\text { Al, Si, Ca, } \\
\text { Ti(a), Mn, } \\
\text { Ni, Cu, Zn, } \\
\text { Br }\end{array}$ & $\mathrm{Fe}, \mathrm{Cu}$ & $\begin{array}{l}\mathrm{Si}, \mathbf{C r}, \\
\mathbf{M n}, \mathbf{F e}, \\
\mathrm{Ni}, \mathbf{Z n}, \\
\mathrm{Rb}, \mathbf{P b}, \\
\mathrm{T}_{\mathrm{a}}(\mathrm{a})\end{array}$ & $\begin{array}{l}\mathbf{A l}, \mathrm{Fe}, \mathrm{Cu} \\
\mathbf{Z n}, \mathrm{Pb}, \mathbf{E C}\end{array}$ \\
\hline $\mathrm{Ca}$ & $\begin{array}{l}\mathbf{P}, \mathrm{S}, \mathrm{Cl}, \\
\mathbf{N i}, \mathbf{C u}, \\
\mathrm{RH}\end{array}$ & $\begin{array}{l}\text { Al, Si, Ti, } \\
\text { Mn, Fe, } \\
\mathrm{Cu}, \mathbf{Z n}, \\
\mathrm{Rb}, \mathbf{P b}, \\
\text { EC }\end{array}$ & $\begin{array}{l}\text { Al, Si, P, } \\
\text { S, Cl, V, } \\
\text { Mn, Fe, } \\
\text { Ni, Cu, } \\
\text { Zn, Br, EC }\end{array}$ & $\begin{array}{l}\text { Al, Si, Ti, } \\
\text { Cr, Mn, } \\
\text { Fe, Ni, Cu, } \\
\text { EC, T }, \\
\text { WS(a) }\end{array}$ & $\begin{array}{l}\text { Si, P, S, Mn, } \\
\text { Fe, Ni, Cu, } \\
\text { Zn, Se, Pb, } \\
\text { EC, OC, } \\
\text { TC, } \text { PM }_{2.5}, \\
\text { WS(a) }\end{array}$ & - & $\begin{array}{l}\text { Al, Si, P, } \\
\text { S, Cl, Mn, } \\
\text { Ni, Cu, } \\
\text { Zn, Br, Pb }\end{array}$ & $\begin{array}{l}\text { Al, Mn, } \\
\text { Ni, Cu, } \\
\text { Rb, Sr, } \\
\text { RH, PR }\end{array}$ & $\begin{array}{l}\text { Al, Si, Cl, } \\
\text { Mn, Ni, Cu, } \\
\text { Zn, Br }\end{array}$ & $\begin{array}{l}\text { Mn, Ni, } \\
\text { Cu, Sr, } \\
\text { Pb(a), } \\
\text { EC(a), PR, } \\
\text { WS }\end{array}$ & $\mathrm{Cr}, \mathrm{RH}$ & $\mathrm{PR}, \mathrm{T}_{\mathrm{a}}(\mathrm{a})$ \\
\hline $\mathrm{Ti}$ & $\mathrm{T}_{\mathrm{a}}$ & $\begin{array}{l}\text { Al, } \mathrm{Si}, \mathrm{Cr}, \\
\mathbf{M n}, \mathbf{F e}, \\
\mathrm{Zn}, \mathrm{Pb}, \mathbf{E C}\end{array}$ & $\mathrm{P}, \mathrm{V}, \mathrm{Ni}$ & $\begin{array}{l}\text { Al, Si, V, } \\
\text { Cr, Mn, } \\
\text { Fe, Ni, Cu, } \\
\text { EC, T, } \\
\text { WS(a) }\end{array}$ & $\begin{array}{l}\mathrm{P}, \mathrm{Al}, \mathrm{Si}, \mathrm{Se}, \\
\mathrm{PM}_{2.5}\end{array}$ & $\mathbf{V}, \mathbf{S i}$ & $\begin{array}{l}\mathrm{PM}_{2.5}, \mathrm{RH}, \\
\mathrm{P}_{\mathrm{a}}(\mathrm{a})\end{array}$ & $\begin{array}{l}\mathrm{EC}, \mathrm{PM}_{10} \\
\mathrm{P}_{\mathrm{a}}\end{array}$ & $\begin{array}{l}\mathrm{S}(\mathrm{a}), \mathbf{C l}, \\
\mathrm{PM}_{2.5} \text { (a) }\end{array}$ & - & $\begin{array}{l}\mathrm{Cl}(\mathrm{a}), \mathrm{Ni}, \\
\mathbf{B r},\end{array}$ & - \\
\hline
\end{tabular}




\begin{tabular}{|c|c|c|c|c|c|c|c|c|c|c|c|c|}
\hline $\mathrm{V}$ & $\begin{array}{l}\mathrm{Al}, \mathbf{P}, \mathrm{S}, \\
\mathbf{B r}\end{array}$ & $\begin{array}{l}\text { Al, Si, Ni, } \\
\text { Rb, Sr, } \\
\mathrm{PM}_{10}\end{array}$ & $\begin{array}{l}\text { Al, Si, P, } \\
\text { S, Cl, Mn, } \\
\text { Fe, Ni, Br, } \\
\text { EC }\end{array}$ & $\begin{array}{l}\text { Al, Si, Fe, } \\
\text { Ni, WS(a) }\end{array}$ & $\begin{array}{l}\mathrm{Ni}, \mathrm{PM}_{2.5}(\mathrm{a}), \\
\mathrm{WS}(\mathrm{a}), \mathrm{P}_{\mathrm{a}}\end{array}$ & - & - & - & $\mathrm{PM}_{2.5}$ & - & $\begin{array}{l}\mathbf{P}, \mathbf{S}, \mathbf{N i}, \\
\mathbf{B r}, \mathrm{Pb},\end{array}$ & $\begin{array}{l}\mathbf{N i}, \mathrm{PM}_{2.5}, \\
\text { WS }\end{array}$ \\
\hline $\mathrm{Cr}$ & $\begin{array}{l}\mathrm{Al}, \mathrm{Si}, \mathbf{C l}, \\
\mathrm{Mn}, \mathrm{Sr}, \\
\text { RH(a), } \\
\text { EC, TC }\end{array}$ & $\begin{array}{l}\mathrm{PM}_{2.5}, \\
\mathrm{WS}(\mathrm{a})\end{array}$ & $\mathrm{Cl}, \mathrm{Se}$ & $\begin{array}{l}\mathrm{Al}, \mathrm{Si}, \mathbf{M n}, \\
\mathrm{Fe}, \mathrm{Cu}, \\
\mathrm{RH}(\mathrm{a})\end{array}$ & - & $\begin{array}{l}\text { RH(a), } \\
\text { WS(a) }\end{array}$ & - & $\mathrm{Mn}, \mathrm{T}_{\mathrm{a}}(\mathrm{a})$ & $\begin{array}{l}\text { Mn, Ni, Cu, } \\
\text { Zn, Br, } \\
\mathrm{PM}_{2.5} \text { (a) }\end{array}$ & $\begin{array}{l}\text { Mn, Fe, } \\
\mathrm{Zn},\end{array}$ & $\begin{array}{l}\mathrm{Si}, \mathbf{M n}, \\
\mathrm{Fe}, \mathbf{Z n}, \\
\mathrm{Rb}, \mathrm{Pb}, \\
\mathrm{PR}\end{array}$ & $\begin{array}{l}\mathbf{Z n}, \mathrm{Pb} \\
\mathrm{PM}_{2.5}\end{array}$ \\
\hline $\mathrm{Mn}$ & $\begin{array}{l}\text { Al, Si, Cl, } \\
\text { Fe, Zn, } \\
\text { Br, Rb, } \\
\text { Pb, EC, } \\
\text { TC }\end{array}$ & $\begin{array}{l}\text { Al, Si, Fe, } \\
\mathrm{Cu}, \mathbf{Z n}, \\
\mathbf{R b}, \mathrm{T}_{\mathrm{a}}\end{array}$ & $\begin{array}{l}\text { Al, Si, P, } \\
\text { S, Cl, Fe, } \\
\text { Zn, Br, } \\
\text { Rb, Pb, } \\
\text { EC, OC, } \\
\text { TC }\end{array}$ & $\begin{array}{l}\text { Al, Si, Fe, } \\
\text { Ni, Cu, } \\
\text { Zn, Rb, } \\
\text { Pb, EC, } \\
\text { OC, TC, } \\
\text { RH(a), } \\
\text { WS(a) }\end{array}$ & $\begin{array}{l}\text { Si, P, S, } \\
\mathrm{Cl}(\mathrm{a}), \mathbf{F e}, \\
\mathrm{Ni}, \mathbf{C u}, \mathbf{Z n}, \\
\text { Se, Pb, EC, } \\
\text { OC, TC, } \\
\text { PM }_{2.5}, \\
\text { WS(a) }^{-}\end{array}$ & $\begin{array}{l}\text { Fe, Cu, } \\
\text { Zn, Rb, } \\
\text { Pb, EC, } \\
\text { OC, TC, } \\
\text { PR(a), } \mathbf{P}_{\mathbf{a}}, \\
\text { WS(a) }\end{array}$ & $\begin{array}{l}\mathrm{Al}, \mathrm{Si}, \mathbf{P}, \\
\mathrm{S}, \mathrm{Cl}, \mathrm{Ni}, \\
\mathrm{Cu}, \mathrm{Zn}, \\
\mathrm{Br}, \mathbf{P b}, \\
\mathbf{P M}_{2.5}\end{array}$ & $\begin{array}{l}\text { Al, Fe, Ni, } \\
\mathbf{C u}, \mathbf{Z n}, \\
\text { Rb, Pb, } \\
\mathbf{P M}_{2.5}, \text { EC }\end{array}$ & $\begin{array}{l}\text { Al, } \mathbf{S i}, \mathrm{Fe}, \\
\mathrm{Ni}, \mathbf{Z n},\end{array}$ & $\begin{array}{l}\text { Fe, Ni, Cu, } \\
\text { Zn, PR }\end{array}$ & $\begin{array}{l}\mathbf{F e}, \mathbf{Z n}, \\
\mathrm{Br}, \mathbf{R b}, \\
\mathbf{P b}, \mathrm{T}_{\mathrm{a}}(\mathrm{a})\end{array}$ & $\begin{array}{l}\text { Fe, } \mathrm{Ni}, \mathrm{Cu}, \\
\mathrm{Zn}, \mathrm{Pb}, \\
\mathrm{RH}(\mathrm{a})\end{array}$ \\
\hline $\mathrm{Fe}$ & $\begin{array}{l}\text { Al, Cl, Zn, } \\
\text { Rb, Pb, } \\
\text { EC, OC, } \\
\text { TC, WS, } \\
\text { T }_{\mathrm{a}}, \mathrm{PR}, \\
\mathrm{P}_{\mathrm{a}}(\mathrm{a})\end{array}$ & $\begin{array}{l}\text { Al, Si, Zn, } \\
\text { Rb, Pb, } \\
\text { EC }\end{array}$ & $\begin{array}{l}\text { Al, Si, P, } \\
\text { S, Cl, Cu, } \\
\text { Zn, Br, } \\
\text { Pb, EC, } \\
\text { OC, TC, } \\
\mathrm{T}_{\mathrm{a}}(\mathrm{a}), \mathbf{P}_{\mathrm{a}}, \\
\text { PR(a), } \\
\text { WS(a) }\end{array}$ & $\begin{array}{l}\text { Al, Si, Ni, } \\
\text { Cu, Zn, } \\
\text { Rb, Pb, } \\
\text { EC, OC, } \\
\text { TC, } \\
\text { RH(a), T } \\
\text { WS(a) }\end{array}$ & $\begin{array}{l}\mathrm{Al}, \mathbf{S i}, \mathbf{P}, \mathbf{S}, \\
\mathrm{Ni}, \mathbf{C u}, \mathbf{Z n}, \\
\mathrm{Br}, \mathrm{Rb}, \mathrm{Sr}, \\
\mathbf{P b}, \mathbf{E C}, \\
\text { OC, TC, } \\
\text { PM }_{2.5}, \\
\text { WS(a) }\end{array}$ & $\begin{array}{l}\text { Cu, Zn, } \\
\text { Rb, Pb, } \\
\text { EC, OC, } \\
\text { TC, } \\
\text { PR(a), } P_{a}, \\
\text { WS(a) }\end{array}$ & $\begin{array}{l}\mathbf{S}, \mathbf{P b}, \mathbf{E C}, \\
\mathrm{P}_{\mathrm{a}}, \mathrm{WS}(\mathrm{a})\end{array}$ & $\begin{array}{l}\mathrm{Zn}, \mathbf{P b}, \\
\text { EC, OC, } \\
\text { TC, } \\
\mathbf{W S}(\mathbf{a}), \mathbf{P}_{\mathrm{a}}\end{array}$ & $\begin{array}{l}\text { Al, Si, P, S, } \\
\mathrm{Sr}, \mathbf{P b}, \mathbf{R H}, \\
\mathbf{T}_{\mathbf{a}}(\mathbf{a})\end{array}$ & $\begin{array}{l}\mathrm{Si}, \mathrm{Zn}, \mathrm{Pb}, \\
\text { EC }\end{array}$ & $\begin{array}{l}\text { Al, Si, P, } \\
\mathbf{S}, \mathrm{Cu}, \\
\mathbf{Z n}, \mathrm{Br}, \\
\mathrm{Rb}, \mathbf{P b},\end{array}$ & $\begin{array}{l}\text { Al, Si, Cu, } \\
\text { Zn, Pb, EC, } \\
\text { RH(a), } \mathbf{T}_{\mathbf{a}}, \\
\text { WS(a) }\end{array}$ \\
\hline $\mathrm{Ni}$ & $\begin{array}{l}\mathbf{S i}, \mathbf{P}, \mathbf{C l}, \\
\mathbf{C u}, \mathbf{Z n}, \\
\text { Br, Sr, } \\
\text { OC, T, } \\
\text { RH, PR }\end{array}$ & $\begin{array}{l}\mathrm{Al}, \mathrm{Si}, \\
\mathbf{P M}_{10}\end{array}$ & $\mathrm{Se}, \mathrm{T}_{\mathrm{a}}$ & $\begin{array}{l}\text { Al, } \mathrm{Si}, \mathrm{Cu}, \\
\text { EC, OC, } \\
\text { TC, } \mathrm{T}_{\mathrm{a}}, \\
\mathbf{W S}(\mathbf{a})\end{array}$ & $\begin{array}{l}\mathrm{P}, \mathrm{Cu}, \mathrm{EC}, \\
\text { PM }_{2.5}, \\
\text { WS(a) }\end{array}$ & - & $\begin{array}{l}\text { Al, Si, P, } \\
\text { S, Cl, Cu, } \\
\text { Zn, Br, Sr, } \\
\text { Pb, }\end{array}$ & $\begin{array}{l}\text { Al, Cu, } \\
\text { Rb, RH, } \\
\text { PR }\end{array}$ & $\begin{array}{l}\mathrm{Al}, \mathbf{C u}, \mathbf{Z n}, \\
\text { Br, PR(a) }\end{array}$ & $\begin{array}{l}\text { Cu, Pb(a), } \\
\text { EC(a), } \\
\text { RH, PR, } \\
\text { WS }\end{array}$ & $\begin{array}{l}\text { Al, P, S, } \\
\mathrm{Cu}, \mathrm{Br}, \\
\mathbf{P b}, \\
\mathrm{PM}_{2.5}\end{array}$ & $\mathrm{PM}_{2.5}$ \\
\hline $\mathrm{Cu}$ & $\begin{array}{l}\text { Si, P, Cl, } \\
\text { Zn, Br, } \\
\text { EC, OC, } \\
\text { TC, T }, \\
\text { RH, PR }\end{array}$ & $\mathrm{Zn}, \mathrm{Rb}, \mathrm{Pb}$ & $\begin{array}{l}\text { Al, Si, P, } \\
\text { S, Cl, Zn, } \\
\text { Br, Pb, } \\
\text { EC, OC, } \\
\text { TC, PR(a), } \\
\text { P }_{a}, W S(a) \\
\text { WD(a) }\end{array}$ & $\begin{array}{l}\text { Al, Si, Zn, } \\
\text { Rb, Pb, } \\
\text { EC, OC, } \\
\text { TC, RH(a) }\end{array}$ & $\begin{array}{l}\text { P, S, Zn, Br, } \\
\text { Pb, EC, } \\
\text { OC, TC, } \\
\text { WS(a) }\end{array}$ & $\begin{array}{l}\text { Zn, Rb, } \\
\text { Pb, EC, } \\
\text { OC, TC, } \\
\text { PM }_{2.5} \\
\text { PR(a), } \\
\text { WS(a) }\end{array}$ & $\begin{array}{l}\text { Al, Si, P, } \\
\text { S, Cl, Zn, } \\
\text { Br, Pb, } \\
\text { PM }_{2.5}\end{array}$ & $\begin{array}{l}\text { Al, Rb, } \\
\text { RH }\end{array}$ & $\begin{array}{l}\mathrm{Al}, \mathbf{Z n}, \mathbf{B r}, \\
\mathrm{Rb}(\mathrm{a})\end{array}$ & $\mathrm{Sr}, \mathrm{RH}$ & Al, $\mathbf{P}$ & $\begin{array}{l}\text { Al, } \mathrm{Si}, \mathrm{Zn}, \\
\mathbf{P b}, \mathbf{E C}, \mathbf{T}_{\mathbf{a}}\end{array}$ \\
\hline $\mathrm{Zn}$ & $\begin{array}{l}\text { Si, Cl, Br, } \\
\text { Pb, EC, } \\
\text { OC, TC, } \\
\mathrm{T}_{\mathrm{a}}, \mathrm{RH},\end{array}$ & $\begin{array}{l}\text { Al, Si, Rb, } \\
\text { Pb, RH(a), } \\
\mathrm{T}_{\mathrm{a}}, \mathrm{EC}\end{array}$ & $\begin{array}{l}\text { Al, Si, S, } \\
\text { P, Cl, Br, } \\
\text { Rb, Pb, } \\
\text { EC, OC, }\end{array}$ & $\begin{array}{l}\mathrm{Al}, \mathbf{R b}, \\
\mathbf{P b}, \mathbf{E C}, \\
\text { OC, TC, } \\
\text { RH(a) }\end{array}$ & $\begin{array}{l}\mathrm{Si}, \mathbf{P}, \mathbf{S}, \mathrm{Br}, \\
\mathbf{P b}, \mathbf{E C}, \\
\mathbf{O C}, \mathbf{T C}, \\
\mathbf{P M}_{2.5}\end{array}$ & $\begin{array}{l}\text { Rb, Pb, } \\
\text { EC, OC, } \\
\text { TC, } \\
\text { PR(a), } \mathbf{P}_{\mathrm{a}},\end{array}$ & $\begin{array}{l}\text { Al, Si, S, } \\
\text { Cl, Br, Pb, } \\
\text { P, PM } 2.5\end{array}$ & Al, Pb, EC & $\mathrm{Al}, \mathrm{Br}$ & $\mathrm{Si}, \mathrm{EC}$ & $\begin{array}{l}\mathrm{Si}, \mathrm{Br}, \\
\mathrm{Rb}, \mathbf{P b}, \\
\mathrm{T}_{\mathrm{a}}(\mathrm{a})\end{array}$ & $\begin{array}{l}\mathbf{P b}, \mathrm{EC}, \\
\mathrm{PM}_{2.5}\end{array}$ \\
\hline
\end{tabular}




\begin{tabular}{|c|c|c|c|c|c|c|c|c|c|c|c|c|}
\hline & PR & & $\begin{array}{l}\text { TC, } \mathbf{P}_{\mathrm{a}} \\
\text { WS(a) }\end{array}$ & & WS(a) & WS(a) & & & & & & \\
\hline $\mathrm{Rb}$ & $\begin{array}{l}\text { Se, Pb, } \\
\text { EC, OC, } \\
\text { TC, } \text { PM }_{10}\end{array}$ & $\begin{array}{l}\mathrm{Si}, \mathbf{P b}, \\
\mathrm{PM}_{2.5}\end{array}$ & $\begin{array}{l}\mathrm{Al}, \mathrm{Si}, \mathbf{P} \\
\mathrm{S}, \mathrm{Cl}, \mathrm{EC}, \\
\mathrm{OC}, \mathrm{TC}\end{array}$ & $\begin{array}{l}\text { Pb, EC, } \\
\text { OC, TC, } \\
\text { WS(a) }\end{array}$ & $\begin{array}{l}\text { EC, OC, TC, } \\
\text { WS(a) }\end{array}$ & $\begin{array}{l}\text { Pb, EC, } \\
\text { OC, TC, } \\
\text { RH, } \\
\text { PR(a), } \mathbf{P}_{\mathrm{a}}\end{array}$ & - & $\mathbf{A l}, \mathbf{S i}(\mathbf{a})$ & $\begin{array}{l}\text { Sr, } \mathrm{PM}_{2.5}, \\
\mathrm{RH}, \mathrm{PR}\end{array}$ & $\mathrm{Al}, \mathrm{EC}(\mathrm{a})$ & $\mathrm{S}, \mathbf{P b}$ & - \\
\hline $\mathrm{Sr}$ & $\mathbf{A l}, \mathbf{S i}$ & - & - & - & $\mathrm{Si}$ & - & $\mathrm{Al}$ & Al & $\mathrm{Al}$ & - & - & $P_{a}(a)$ \\
\hline$\overline{\mathrm{Pb}}$ & $\begin{array}{l}\text { Al, Cl, EC, } \\
\text { OC, TC }\end{array}$ & $\begin{array}{l}\mathbf{A l}, \mathbf{S i}, \mathrm{T}_{\mathrm{a}}, \\
\text { WS }\end{array}$ & $\begin{array}{l}\text { Al, Si, P, } \\
\text { S, Cl, } \\
\text { PM }_{2.5}, \\
\text { PM }_{10}, \mathbf{E C}, \\
\text { OC, TC, } \\
\text { T }_{\mathbf{a}}(\mathbf{a}), \mathbf{P}_{\mathrm{a}}, \\
\text { WS(a) }\end{array}$ & $\begin{array}{l}\text { EC, OC, } \\
\text { TC }\end{array}$ & $\begin{array}{l}\mathrm{Al}, \mathbf{S i}, \mathbf{P}, \mathbf{S}, \\
\mathrm{EC}, \mathbf{O C}, \\
\mathrm{TC}, \mathbf{P M}_{2.5} \\
\mathrm{WS}(\mathbf{a})\end{array}$ & $\begin{array}{l}\mathrm{Al}, \mathbf{E C}, \\
\text { OC, } \mathbf{T C}, \\
\text { PM }_{2.5}, \\
\text { PR(a), } \\
\text { WS(a) }\end{array}$ & $\begin{array}{l}\text { Al, Si, P, } \\
\text { S, Cl, } \\
\text { PM }_{2.5}\end{array}$ & $\begin{array}{l}\text { EC, OC, } \\
\text { TC, } \\
\text { WS(a), } P_{\mathrm{a}}\end{array}$ & $\begin{array}{l}\mathrm{Al}, \mathrm{Si}, \mathbf{P}, \mathrm{S}, \\
\mathrm{RH}, \mathrm{T}_{\mathrm{a}}(\mathbf{a}),\end{array}$ & $\begin{array}{l}\text { EC, RH, } \\
\text { WS }\end{array}$ & $\begin{array}{l}\text { Al, Si, P, } \\
\mathbf{S}, \mathrm{T}_{\mathrm{a}}(\mathrm{a})\end{array}$ & $\begin{array}{l}\text { EC, } \text { PM }_{2.5}, \\
\text { WS(a) }\end{array}$ \\
\hline $\mathrm{Al}$ & $\begin{array}{l}\text { Si, }, \mathbf{P}, \mathbf{S}, \\
\mathbf{E C}\end{array}$ & $\mathbf{S i}, \mathrm{EC}, \mathrm{T}_{\mathrm{a}}$ & $\begin{array}{l}\text { Si, P, S, } \\
\text { Cl, EC, } \\
\text { OC, TC, } \\
\text { PM }_{2.5}, \\
\text { PM }_{10}\end{array}$ & $\begin{array}{l}\text { Si, EC, } \\
\text { OC, TC, } \\
\text { RH(a), } \mathbf{T}_{a}, \\
\text { WS(a) }\end{array}$ & $\begin{array}{l}\mathbf{S i}, \mathbf{P}, \mathbf{S}, \mathrm{OC}, \\
\mathbf{P M}_{2.5}, \mathbf{T}_{\mathbf{a}}\end{array}$ & Si & $\begin{array}{l}\mathrm{Si}, \mathbf{P}, \mathbf{S}, \\
\mathrm{Cl}, \mathbf{P M}_{2.5}\end{array}$ & $\mathrm{RH}$, & $\begin{array}{l}\mathrm{Si}, \mathbf{P M}_{10} \\
\mathbf{R H}, \mathbf{T}_{\mathbf{a}}(\mathbf{a})\end{array}$ & $\mathrm{Si}$ & $\begin{array}{l}\mathbf{P}, \mathrm{S}, \\
\mathrm{PM}_{2.5},\end{array}$ & $\begin{array}{l}\mathrm{Si}, \mathbf{E C}, \mathbf{T}_{\mathbf{a}}, \\
\text { WS(a) }\end{array}$ \\
\hline $\mathrm{Si}$ & $\mathrm{P}, \mathrm{S}, \mathbf{C l}$ & - & $\begin{array}{l}\text { P, S, Cl, } \\
\text { EC, OC, } \\
\text { TC }\end{array}$ & $\begin{array}{l}\text { EC, } \mathbf{T}_{\mathbf{a}}, \\
\mathrm{WS}(\mathbf{a})\end{array}$ & $\begin{array}{l}\mathbf{P}, \mathbf{S}, \mathrm{Cl}(\mathrm{a}) \\
\mathrm{EC}, \mathbf{O C}, \\
\mathbf{T C}, \mathbf{P M}_{2.5} \\
\mathbf{T}_{\mathbf{a}}\end{array}$ & - & $\begin{array}{l}\mathbf{P}, \mathbf{S}, \mathbf{C l}, \\
\mathrm{PM}_{2.5}\end{array}$ & $\begin{array}{l}\mathbf{E C}, \mathbf{P M}_{10} \\
\mathbf{T}_{\mathrm{a}}, \mathbf{P}_{\mathrm{a}}\end{array}$ & $\begin{array}{l}\mathrm{P}, \mathbf{S}, \mathbf{R H}, \\
\mathbf{T}_{\mathrm{a}} \text { (a) }\end{array}$ & - & $\begin{array}{l}\mathrm{RH}(\mathrm{a}), \\
\mathrm{T}_{\mathrm{a}}(\mathrm{a})\end{array}$ & $\begin{array}{l}\text { EC, RH(a), } \\
T_{a}\end{array}$ \\
\hline $\mathrm{Br}$ & $\begin{array}{l}\text { Al, Si, P, } \\
\text { S, Cl, Rb, } \\
\text { Pb, EC, } \\
\text { OC, TC }\end{array}$ & n.a. & $\begin{array}{l}\text { Al, Si, P, } \\
\text { S, Cl, Rb, } \\
\text { Pb, EC, } \\
\text { OC, TC, } \\
\text { RH, WS(a) }\end{array}$ & n.a. & $\mathbf{P}, \mathbf{S}, \mathbf{P b}, \mathrm{EC}$ & n.a. & $\begin{array}{l}\text { Al, Si, P, } \\
\text { S, Cl, Pb, } \\
\text { PM }_{2.5}\end{array}$ & n.a. & $\mathrm{PM}_{2.5}(\mathrm{a})$ & n.a. & $\mathrm{P}, \mathrm{S}, \mathbf{P b}$, & n.a. \\
\hline S & $\begin{array}{l}\mathrm{P}, \mathrm{Se}, \mathrm{EC}, \\
\mathrm{P}_{\mathrm{a}}, \mathrm{T}(\mathrm{a}), \\
\mathrm{WS}(\mathrm{a})\end{array}$ & n.a. & $\begin{array}{l}\text { P, Cl, EC, } \\
\text { OC, TC, } \\
\text { WS(a) }\end{array}$ & n.a. & $\begin{array}{l}\text { P, EC, OC, } \\
\text { TC, RH, } \\
\text { WS(a) }\end{array}$ & n.a. & $\begin{array}{l}\mathbf{P}, \mathbf{C l}, \\
\text { PM }_{2.5}\end{array}$ & n.a. & $\begin{array}{l}\text { P, RH, } \\
T_{a}(a), P R\end{array}$ & n.a. & $\mathrm{P}, \mathrm{PM}_{2.5}$ & n.a. \\
\hline $\mathrm{Cl}$ & $\begin{array}{l}\mathbf{T}_{\mathbf{a}}, \mathbf{R H}, \\
\text { PR, WS, } \\
\mathbf{P}_{\mathrm{a}}(\mathbf{a})\end{array}$ & n.a. & $\begin{array}{l}\text { P, EC, } \\
\text { OC, TC, } \\
\text { WS(a) }\end{array}$ & n.a. & $\begin{array}{l}\mathbf{O C}(\mathbf{a}), \\
\mathrm{TC}(\mathrm{a}), \mathbf{T}_{\mathrm{a}}(\mathbf{a})\end{array}$ & n.a. & $\mathbf{P}, \mathrm{PM}_{2.5}$ & n.a. & $T_{a}$ & n.a. & $\begin{array}{l}\mathrm{PM}_{2.5}(\mathrm{a}), \\
\mathbf{R H}\end{array}$ & n.a. \\
\hline $\mathrm{P}$ & $\begin{array}{l}\mathrm{P}_{\mathrm{a}}, \mathbf{W S}(\mathbf{a}), \\
\mathbf{E C}, \mathrm{OC}\end{array}$ & n.a. & $\begin{array}{l}\text { EC, OC, } \\
\text { TC, } \\
\text { WS(a), } \\
\text { RH }\end{array}$ & n.a. & $\begin{array}{l}\text { EC, OC, } \\
\text { TC, WS(a) }\end{array}$ & n.a. & $\mathrm{PM}_{2.5}$, & n.a. & $\mathbf{R H}, \mathbf{T}_{\mathrm{a}}(\mathbf{a})$ & n.a. & Se, $\mathrm{PM}_{2.5}$ & n.a. \\
\hline
\end{tabular}


Abbreviations: EC - elemental carbon, $\mathrm{OC}$ - organic carbon, $\mathrm{TC}$ - total carbon, $\mathrm{RH}-$ relative humidity, $\mathrm{PR}-$ precipitation, $\mathrm{WS}-$ wind-speed, $\mathrm{T}_{\mathrm{a}}-$ air-temperature, $\mathrm{P}_{\mathrm{a}}-$

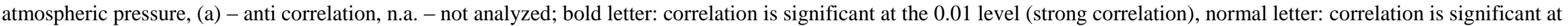
the 0.05 level (some correlation) 
Supplementary Table 2: PCA of elements at Petroleumkaai

\begin{tabular}{|c|c|c|c|c|c|c|}
\hline \multicolumn{7}{|c|}{ Rotated Component Matrix $^{\dagger}$} \\
\hline \multirow[t]{2}{*}{ Species } & \multicolumn{6}{|c|}{ Factor } \\
\hline & 1 & 2 & 3 & 4 & 5 & 6 \\
\hline $\mathrm{Al}$ & -0.01 & 0.94 & -0.17 & 0.05 & 0.21 & 0.01 \\
\hline $\mathrm{Si}$ & 0.09 & 0.91 & -0.18 & 0.13 & 0.18 & -0.13 \\
\hline $\mathrm{P}$ & 0.73 & 0.58 & -0.11 & 0.26 & -0.07 & -0.04 \\
\hline$S$ & 0.79 & 0.47 & 0.08 & 0.26 & -0.08 & -0.14 \\
\hline $\mathrm{Cl}$ & -0.27 & -0.15 & 0.37 & -0.22 & -0.58 & -0.11 \\
\hline $\mathrm{K}$ & 0.92 & 0.11 & 0.26 & -0.07 & 0.02 & -0.02 \\
\hline $\mathrm{Ca}$ & 0.55 & -0.43 & 0.06 & -0.38 & -0.07 & 0.56 \\
\hline $\mathrm{Ti}$ & 0.16 & 0.21 & 0.14 & 0.85 & -0.15 & 0.17 \\
\hline $\mathrm{V}$ & -0.31 & -0.04 & -0.13 & 0.70 & 0.43 & -0.10 \\
\hline $\mathrm{Cr}$ & -0.09 & 0.00 & -0.57 & 0.04 & -0.02 & -0.76 \\
\hline $\mathrm{Mn}$ & 0.00 & -0.07 & 0.10 & 0.23 & -0.27 & 0.80 \\
\hline $\mathrm{Fe}$ & 0.90 & -0.19 & -0.17 & -0.15 & 0.03 & 0.14 \\
\hline $\mathrm{Ni}$ & -0.07 & -0.06 & 0.95 & 0.03 & -0.02 & 0.15 \\
\hline $\mathrm{Cu}$ & 0.87 & -0.13 & -0.12 & -0.17 & 0.31 & 0.23 \\
\hline $\mathrm{Zn}$ & 0.96 & -0.12 & -0.06 & 0.11 & -0.02 & 0.07 \\
\hline $\mathrm{Se}$ & -0.26 & -0.28 & -0.30 & 0.11 & -0.69 & 0.18 \\
\hline $\mathrm{Br}$ & 0.48 & 0.20 & 0.04 & 0.51 & 0.48 & 0.17 \\
\hline $\mathrm{Rb}$ & 0.01 & -0.40 & 0.81 & 0.07 & 0.02 & 0.16 \\
\hline $\mathrm{Sr}$ & -0.28 & 0.07 & -0.02 & 0.03 & 0.67 & -0.30 \\
\hline $\mathrm{Pb}$ & 0.88 & 0.38 & -0.03 & 0.10 & -0.01 & -0.01 \\
\hline Eigenvalue & 6.58 & 4.24 & 2.40 & 1.72 & 1.43 & 1.02 \\
\hline $\begin{array}{l}\text { \% Variance } \\
\text { Explained }\end{array}$ & 32.90 & 21.19 & 12.02 & 8.59 & 7.17 & 5.12 \\
\hline $\begin{array}{l}\text { Major } \\
\text { Sources }\end{array}$ & Refinery & Crustal & $\begin{array}{c}\text { Brake } \\
\text { wear + }\end{array}$ & $\begin{array}{r}\text { Heavy } \\
\text { oil } \\
\text { burning }\end{array}$ & & \\
\hline
\end{tabular}

Extraction Method: Principal Component Analysis.

Rotation Method: Varimax with Kaiser Normalization.

${ }^{\dagger}$ Rotation converged in 14 iterations. 
Supplementary Table 3: PCA of elements at Borgerhout

\begin{tabular}{|c|c|c|c|c|c|}
\hline \multicolumn{6}{|c|}{ Rotated Component Matrix ${ }^{\dagger}$} \\
\hline \multirow[t]{2}{*}{ Species } & \multicolumn{5}{|c|}{$\begin{array}{r}\text { Factor } \\
\end{array}$} \\
\hline & 1 & 2 & 3 & 4 & 5 \\
\hline $\mathrm{Al}$ & 0.97 & 0.14 & 0.04 & -0.09 & 0.13 \\
\hline $\mathrm{Si}$ & 0.95 & 0.22 & 0.05 & -0.01 & 0.15 \\
\hline $\mathrm{P}$ & 0.96 & 0.20 & -0.04 & -0.08 & -0.02 \\
\hline$S$ & 0.94 & 0.16 & -0.09 & -0.11 & -0.06 \\
\hline $\mathrm{Cl}$ & 0.70 & 0.47 & 0.10 & -0.23 & 0.09 \\
\hline $\mathrm{K}$ & 0.94 & 0.31 & -0.01 & 0.02 & 0.00 \\
\hline $\mathrm{Ca}$ & 0.66 & 0.60 & 0.05 & 0.16 & 0.26 \\
\hline $\mathrm{Ti}$ & -0.19 & -0.33 & 0.14 & 0.88 & -0.17 \\
\hline $\mathrm{V}$ & 0.68 & 0.10 & -0.11 & 0.54 & -0.18 \\
\hline $\mathrm{Cr}$ & 0.11 & 0.03 & 0.94 & 0.15 & 0.01 \\
\hline $\mathrm{Mn}$ & 0.39 & -0.29 & -0.62 & 0.25 & 0.19 \\
\hline $\mathrm{Fe}$ & 0.51 & 0.80 & 0.13 & -0.07 & -0.11 \\
\hline $\mathrm{Ni}$ & -0.46 & 0.26 & -0.30 & 0.45 & 0.37 \\
\hline $\mathrm{Cu}$ & 0.29 & 0.93 & 0.05 & -0.16 & 0.03 \\
\hline $\mathrm{Zn}$ & 0.74 & 0.58 & -0.09 & -0.07 & -0.09 \\
\hline $\mathrm{Se}$ & 0.10 & -0.01 & -0.12 & -0.10 & 0.80 \\
\hline $\mathrm{Br}$ & 0.86 & 0.20 & 0.07 & -0.08 & 0.26 \\
\hline $\mathrm{Sr}$ & -0.13 & 0.63 & -0.20 & 0.07 & -0.65 \\
\hline $\mathrm{Pb}$ & 0.49 & 0.71 & 0.29 & -0.17 & -0.13 \\
\hline Eigenvalue & & & & & \\
\hline & 9.96 & 2.57 & 1.59 & 1.52 & 1.12 \\
\hline $\begin{array}{l}\text { \% Variance } \\
\text { Explained }\end{array}$ & 52.40 & 13.52 & 8.39 & 8.01 & 5.9 \\
\hline $\begin{array}{l}\text { Major } \\
\text { Sources }\end{array}$ & Vehicular & $\begin{array}{r}\text { Non- } \\
\text { exhaust }\end{array}$ & $\begin{array}{r}\text { Non- } \\
\text { ferrous } \\
\text { industry }\end{array}$ & $\begin{array}{r}\text { Heavy } \\
\text { oil } \\
\text { burning }\end{array}$ & \\
\hline
\end{tabular}

${ }^{\dagger}$ Rotation converged in 11 iterations. 
Supplementary Table 4: PCA of elements at Zelzate

\begin{tabular}{|c|c|c|c|c|c|}
\hline \multicolumn{6}{|c|}{ Rotated Component Matrix ${ }^{\dagger}$} \\
\hline \multirow{2}{*}{ Species } & \multicolumn{5}{|c|}{ Component } \\
\hline & 1 & 2 & 3 & 4 & 5 \\
\hline $\mathrm{Al}$ & 0.78 & 0.09 & 0.11 & 0.31 & 0.12 \\
\hline $\mathrm{Si}$ & 0.66 & -0.30 & 0.39 & 0.09 & -0.08 \\
\hline $\mathrm{P}$ & 0.70 & 0.64 & -0.13 & 0.08 & 0.10 \\
\hline $\mathrm{S}$ & 0.62 & 0.73 & -0.03 & 0.01 & 0.12 \\
\hline $\mathrm{Cl}$ & 0.88 & 0.02 & 0.16 & -0.09 & -0.34 \\
\hline $\mathrm{K}$ & 0.89 & 0.00 & 0.23 & -0.06 & 0.20 \\
\hline $\mathrm{Ca}$ & 0.06 & -0.06 & -0.08 & 0.93 & 0.08 \\
\hline $\mathrm{Ti}$ & -0.22 & -0.05 & -0.03 & -0.14 & -0.77 \\
\hline $\mathrm{V}$ & 0.07 & 0.34 & 0.79 & -0.01 & -0.16 \\
\hline $\mathrm{Cr}$ & -0.16 & 0.83 & 0.23 & 0.03 & -0.15 \\
\hline $\mathrm{Mn}$ & 0.38 & -0.09 & 0.70 & -0.18 & 0.34 \\
\hline $\mathrm{Fe}$ & 0.77 & 0.21 & 0.20 & 0.47 & 0.12 \\
\hline $\mathrm{Ni}$ & 0.45 & 0.39 & 0.43 & 0.26 & 0.10 \\
\hline $\mathrm{Cu}$ & 0.67 & 0.14 & -0.10 & 0.49 & 0.21 \\
\hline $\mathrm{Zn}$ & 0.92 & 0.07 & 0.18 & 0.11 & 0.21 \\
\hline $\mathrm{Br}$ & 0.79 & 0.42 & 0.30 & 0.08 & 0.08 \\
\hline $\mathrm{Sr}$ & -0.16 & -0.37 & -0.08 & -0.50 & 0.49 \\
\hline $\mathrm{Rb}$ & 0.22 & 0.49 & 0.36 & 0.02 & 0.40 \\
\hline $\mathrm{Pb}$ & 0.88 & 0.20 & 0.02 & 0.04 & 0.24 \\
\hline Eigenvalue & & & & & \\
\hline & 8.87 & 2.11 & 1.79 & 1.30 & 1.13 \\
\hline $\begin{array}{l}\text { \% Variance } \\
\text { Explained }\end{array}$ & 46.70 & 11.12 & 9.40 & 6.82 & 5.96 \\
\hline $\begin{array}{l}\text { Major } \\
\text { Sources }\end{array}$ & $\begin{array}{c}\text { Coke- } \\
\text { Oven }\end{array}$ & Combustion & $\begin{array}{l}\text { Traffic } \\
\text { (diesel) }\end{array}$ & $\begin{array}{r}\text { Soil/road } \\
\text { dust }\end{array}$ & \\
\hline
\end{tabular}

${ }^{\dagger}$ Rotation converged in 15 iterations. 
Supplementary Table 5: PCA of elements at Hasselt

\begin{tabular}{|c|c|c|c|c|c|}
\hline \multicolumn{6}{|c|}{ Rotated Component Matrix ${ }^{\dagger}$} \\
\hline \multirow[t]{2}{*}{ Species } & \multicolumn{5}{|c|}{ Component } \\
\hline & 1 & 2 & 3 & 4 & 5 \\
\hline $\mathrm{Al}$ & -0.07 & -0.14 & -0.11 & 0.15 & -0.74 \\
\hline $\mathrm{Si}$ & 0.99 & -0.08 & 0.03 & 0.04 & 0.05 \\
\hline $\mathrm{P}$ & -0.09 & -0.01 & 0.60 & -0.23 & -0.03 \\
\hline$S$ & 0.90 & 0.36 & -0.09 & 0.04 & 0.03 \\
\hline $\mathrm{Cl}$ & 1.00 & -0.05 & 0.00 & 0.00 & -0.01 \\
\hline $\mathrm{K}$ & 0.99 & 0.02 & 0.01 & 0.07 & -0.01 \\
\hline $\mathrm{Ca}$ & 0.99 & -0.09 & 0.04 & 0.01 & -0.01 \\
\hline $\mathrm{Ti}$ & 0.05 & -0.53 & -0.17 & 0.31 & 0.67 \\
\hline $\mathrm{V}$ & -0.10 & -0.07 & -0.06 & -0.92 & 0.09 \\
\hline $\mathrm{Cr}$ & -0.07 & 0.80 & -0.16 & -0.06 & 0.37 \\
\hline $\mathrm{Mn}$ & -0.02 & -0.45 & -0.22 & 0.53 & 0.08 \\
\hline $\mathrm{Fe}$ & 0.07 & 0.93 & 0.01 & 0.06 & -0.16 \\
\hline $\mathrm{Ni}$ & 0.99 & -0.14 & 0.03 & 0.03 & -0.01 \\
\hline $\mathrm{Cu}$ & 0.99 & -0.01 & -0.01 & 0.04 & -0.04 \\
\hline $\mathrm{Zn}$ & 0.99 & 0.11 & -0.03 & 0.06 & -0.03 \\
\hline $\mathrm{Br}$ & 1.00 & -0.03 & 0.01 & -0.01 & 0.03 \\
\hline $\mathrm{Rb}$ & 0.38 & 0.03 & 0.78 & 0.25 & -0.10 \\
\hline $\mathrm{Sr}$ & -0.24 & -0.08 & 0.67 & 0.06 & 0.42 \\
\hline $\mathrm{Pb}$ & 0.86 & 0.45 & -0.09 & 0.08 & 0.06 \\
\hline Eigenvalue & & & & & \\
\hline & 9.73 & 2.52 & 1.58 & 1.33 & 1.25 \\
\hline $\begin{array}{l}\text { \% Variance } \\
\text { Explained }\end{array}$ & 51.20 & 13.24 & 8.33 & 6.98 & 4.61 \\
\hline $\begin{array}{l}\text { Major } \\
\text { Sources }\end{array}$ & Vehicular & $\begin{array}{c}\text { Road } \\
\text { Dust }\end{array}$ & Biomass & $\begin{array}{c}\text { Tyre } \\
\text { wear / } \\
\text { brake } \\
\text { lining }\end{array}$ & \\
\hline
\end{tabular}

${ }^{\dagger}$ Rotation converged in 8 iterations. 
Supplementary Table 6: PCA of elements at Wingene

\begin{tabular}{|c|c|c|c|c|c|c|}
\hline \multicolumn{7}{|c|}{ Rotated Component Matrix ${ }^{\dagger}$} \\
\hline \multirow{2}{*}{ Species } & \multicolumn{6}{|c|}{ Component } \\
\hline & 1 & 2 & 3 & 4 & 5 & 6 \\
\hline $\mathrm{Al}$ & 0.39 & -0.16 & 0.79 & 0.14 & -0.06 & -0.24 \\
\hline $\mathrm{Si}$ & 0.47 & -0.46 & -0.11 & -0.11 & -0.06 & -0.44 \\
\hline $\mathrm{P}$ & 0.44 & 0.19 & 0.51 & 0.53 & 0.35 & -0.02 \\
\hline $\mathrm{S}$ & 0.47 & 0.33 & 0.25 & 0.56 & 0.47 & -0.04 \\
\hline $\mathrm{Cl}$ & -0.22 & -0.06 & -0.03 & 0.89 & 0.00 & -0.07 \\
\hline $\mathrm{K}$ & 0.84 & 0.05 & 0.17 & -0.20 & -0.20 & 0.21 \\
\hline $\mathrm{Ca}$ & 0.18 & -0.15 & 0.19 & 0.03 & 0.20 & 0.81 \\
\hline $\mathrm{Ti}$ & 0.17 & 0.04 & -0.23 & -0.13 & -0.17 & 0.79 \\
\hline V & 0.01 & 0.67 & -0.10 & 0.56 & -0.06 & -0.19 \\
\hline $\mathrm{Cr}$ & -0.36 & -0.22 & 0.08 & 0.08 & -0.76 & -0.01 \\
\hline $\mathrm{Mn}$ & 0.05 & -0.75 & -0.07 & 0.07 & 0.01 & -0.01 \\
\hline $\mathrm{Fe}$ & 0.78 & -0.22 & 0.38 & 0.05 & 0.11 & -0.11 \\
\hline $\mathrm{Ni}$ & 0.39 & 0.74 & 0.25 & 0.16 & 0.22 & -0.02 \\
\hline $\mathrm{Cu}$ & 0.06 & 0.13 & 0.78 & -0.09 & -0.06 & 0.26 \\
\hline $\mathrm{Zn}$ & 0.84 & -0.08 & 0.20 & 0.02 & -0.03 & 0.16 \\
\hline $\mathrm{Se}$ & 0.30 & 0.18 & -0.02 & 0.54 & -0.60 & 0.31 \\
\hline $\mathrm{Br}$ & 0.19 & 0.43 & 0.67 & -0.01 & 0.22 & -0.13 \\
\hline $\mathrm{Rb}$ & 0.67 & 0.35 & -0.03 & -0.13 & 0.12 & 0.16 \\
\hline $\mathrm{Sr}$ & -0.36 & -0.05 & 0.11 & 0.25 & 0.65 & 0.15 \\
\hline $\mathrm{Pb}$ & 0.88 & 0.22 & 0.15 & 0.23 & 0.06 & 0.09 \\
\hline Eigenvalue & 5.98 & 2.99 & 2.05 & 1.79 & 1.52 & 1.39 \\
\hline $\begin{array}{l}\text { \% Variance } \\
\text { Explained }\end{array}$ & 29.88 & 14.97 & 10.25 & 8.95 & 7.61 & 6.94 \\
\hline $\begin{array}{l}\text { Major } \\
\text { Sources }\end{array}$ & Biomass & Fuel oil & Crustal & Sea salt & & \\
\hline
\end{tabular}

${ }^{\dagger}$ Rotation converged in 10 iterations. 
Supplementary Table 7: PCA of elements at Mechelen

\begin{tabular}{|c|c|c|c|c|c|}
\hline \multicolumn{6}{|c|}{ Rotated Component Matrix ${ }^{\dagger}$} \\
\hline \multirow[t]{2}{*}{ Species } & \multicolumn{5}{|c|}{ Component } \\
\hline & 1 & 2 & 3 & 4 & 5 \\
\hline $\mathrm{Al}$ & 0.87 & 0.30 & -0.09 & -0.33 & 0.02 \\
\hline $\mathrm{Si}$ & 0.50 & 0.84 & -0.16 & -0.09 & 0.07 \\
\hline $\mathrm{P}$ & -0.06 & 0.96 & 0.12 & -0.14 & -0.09 \\
\hline $\mathrm{S}$ & 0.15 & 0.97 & -0.12 & 0.09 & 0.09 \\
\hline $\mathrm{Cl}$ & 0.69 & 0.19 & 0.22 & -0.05 & 0.01 \\
\hline $\mathrm{K}$ & 0.97 & 0.23 & -0.03 & 0.02 & -0.05 \\
\hline $\mathrm{Ca}$ & 0.93 & 0.35 & -0.02 & 0.02 & -0.03 \\
\hline $\mathrm{Ti}$ & 0.00 & 0.18 & -0.25 & -0.86 & 0.21 \\
\hline $\mathrm{V}$ & -0.14 & 0.24 & 0.11 & -0.16 & 0.91 \\
\hline $\mathrm{Cr}$ & -0.23 & -0.42 & 0.72 & -0.13 & 0.49 \\
\hline $\mathrm{Mn}$ & -0.29 & 0.18 & -0.59 & 0.63 & -0.15 \\
\hline $\mathrm{Fe}$ & 0.10 & 0.96 & -0.18 & -0.15 & 0.13 \\
\hline $\mathrm{Ni}$ & 0.16 & -0.13 & 0.91 & 0.18 & -0.07 \\
\hline $\mathrm{Cu}$ & 0.79 & 0.16 & 0.52 & 0.04 & 0.10 \\
\hline $\mathrm{Zn}$ & 0.98 & -0.09 & -0.03 & -0.01 & -0.09 \\
\hline $\mathrm{Se}$ & 0.83 & -0.45 & -0.21 & 0.13 & 0.00 \\
\hline $\mathrm{Br}$ & 0.93 & 0.09 & 0.21 & -0.01 & -0.25 \\
\hline $\mathrm{Rb}$ & 0.25 & 0.77 & -0.13 & 0.44 & 0.25 \\
\hline $\mathrm{Sr}$ & -0.06 & 0.55 & -0.13 & 0.62 & 0.49 \\
\hline $\mathrm{Pb}$ & 0.15 & 0.97 & -0.12 & 0.09 & 0.09 \\
\hline Eigenvalue & 8.09 & 5.35 & 2.35 & 1.88 & 1.11 \\
\hline $\begin{array}{l}\text { \% Variance } \\
\text { Explained }\end{array}$ & 40.44 & 26.75 & 11.77 & 9.39 & 5.57 \\
\hline Major Sources & $\begin{array}{r}\text { Local } \\
\text { Industry }\end{array}$ & $\begin{array}{c}\text { Road } \\
\text { Dust }\end{array}$ & $\begin{array}{c}\text { Tyre } \\
\text { wear / } \\
\text { brake } \\
\text { lining }\end{array}$ & & \\
\hline
\end{tabular}

${ }^{\dagger}$ Rotation converged in 8 iterations. 